\title{
Algı Yönetimi Aracı Olarak Twitter Kullanımına İlişkin Siyasal Bir Analiz*
}

\author{
Emine Ceng (Öğr. Gör.) \\ Ondokuz Mayıs Üniversitesi Illetişim Fakültesi \\ emine.ceng@omu.edu.tr
}

Başvuru Tarihi: 30.04.2018

Yayına Kabul Tarihi: 14.07.2018

Yayınlanma Tarihi: 30.07.2018

Öz

Bu çalışmada, Twitter'ın mecliste grubu bulunan siyasi partiler ve liderleri tarafından 7 Haziran 2015 Genel Seçimlerinde kullanımı, algı yönetimi ve sosyal medya ilişkisi bağlamında incelenmektedir. Çalışma ile sosyal medya ve Twitter'ın siyasi partiler tarafından yapısal özellikleri noktasında kullanımının ve söylem biçimlerinin algı yönetimi açısından öneminin ortaya konulması hedeflenmektedir. Bu amaçla, 7 Haziran 2015 Genel Seçimlerine katılan dört partinin (AK Parti, CHP, HDP, MHP) genel başkanları ve MYK üyesi siyasi kişilerinin 1 Mayıs - 10 Haziran tarihleri arasındaki 3757 tweeti nitel ve nicel içerik analizi yöntemi ile analiz edilmiştir. Çalışmada, Twitter'ın algı yönetiminde önemli bir iletişim aracı olarak geleneksel siyasal iletişim araç ve yöntemlerine göre avantajlar taşıdığı, ancak siyasiler tarafından bu mecranın işlevsel olarak kullanılmadığı sonucuna varılmıştır. Çalışma, siyasilere yapacakları siyasal iletişim çalıșmalarında Twitter'ı algı yönetimi çerçevesinde nasıl etkin kullanacakları konusunda farkındalık oluşturmakta ve öneriler sunmaktadır.

Anahtar Kelimeler: Algı Yönetimi, Twitter, Sosyal Medya, 2015 Genel Seçimleri.

\footnotetext{
* Bu çalıșma, Erciyes Üniversitesi Sosyal Bilimler Enstitüsü’ne 2016 yılında sunulan “Algı Yönetimi ve Siyasal İletișim İlișkisi Bağlamında 7 Haziran 2015 Genel Seçimlerinin Sosyal Medya Üzerinden Analizi: Twitter Örneği” başlıkı Yüksek Lisans tezinden türetilmiş makaledir.
} 


\title{
A Political Analysis on the Use of Twitter As a Perception Management Vehicle
}

\author{
Emine Ceng (Lect.) \\ Ondokuz Mayıs University Faculty of Communication \\ emine.ceng@omu.edu.tr
}

Date Received: 30.04 .2018

Date Accepted: 14.07.2018

Date Published: 30.07.2018

\begin{abstract}
The purpose of this study was to investigate use of Twitter for perception management and social media by four Turkish political party leaders before the General Election that occurred on June 7, 2015. In this study, political parties' use of Twitter and its' structural features mentioned above was investigated. Moreover, content of each message was examined to determine how messages contributed to perception management. With this goal in mind, tweets posted between May 1, 2015 and June 10, 2015 by leaders and Central Executive Committee (MYK) members of four political parties (AK Parti, CHP, MHP ve HDP) that participated in the General Election on June 7, 2015 were analyzed using quantitative and qualitative data analyses methods. Findings of the present study showed that within the context of political communication, as a social media tool Twitter has advantages in perception management over traditional methods of communication, but politicians do not use it functionally for this purpose. The present study provides recommendations for politicians about how to use Twitter for perception management within the context of political communication efforts. Further recommendations are provided.
\end{abstract}

Keywords: Twitter, Perception Management, Social Media, 2015 General Elections. 


\section{Giriş}

İnsanların algılarını yönetmek tarih boyunca, siyasi aktörlerin temel amaçları arasında yer almıștır. Çünkü algıları yönetenler, amaçları doğrultusunda diğer insanları daha kolay ve daha zahmetsiz bir șekilde yöneteceklerinin bilincindedirler. Bireyin zorunlu ya da kendi isteğiyle ikna edilmesini veya algısının değiştirilmesini amaçlayan algı yönetimi insanlık tarihinin her döneminde var olmuştur. Gelinen noktada değişen, toplumsal ve teknolojik gelişmelere bağlı olarak bu amaca ulaşmada kullanılan yöntemlerdir.

Dünyada hızla değişen teknoloji, kitle iletişim araçlarını değiştirip geliștirirken hayatın her alanında etkili kılmış, okuyucu, dinleyici ve izleyicilere belli tutum ve değerlerin aktarılmasını ve benimsenmesini sağlayarak siyasal katılıma etki etmiștir. Bu bakımdan algıların yönetimi, teknolojinin gelişmesi ve enformasyonun çok daha hızlı bir şekilde aktarımı sayesinde yeni bir görünüm kazanmıștır. Yaşadığımız bilgi çağında geleneksel propaganda araçları ile toplumun ikna edilme süreci, bireyin aktif kullanıcı olarak yer aldığı web 2.0 diye tanımlanan yeni iletişim ortam ve araçlarının en popüler ve yaygın uygulamaları olan sosyal medya ortamları ile desteklenmeyi gerektiren bir noktaya doğru evrilmiștir. Bilgiye erişim belli bir grubun ayrıcalığı olmaktan çıkarak, toplumun tüm kesimlerinin erișebileceği bir konuma gelmiştir. Günümüzde gündelik yaşamın ayrılmaz bir parçası haline gelen sosyal medya; Facebook, Twitter, Instagram gibi platformlarıyla yaşamın pek çok alanında kişilerin algılarını, davranışlarını, seçimlerini etkileyen bir boyuta ulaşmıştır (High ve Solomon, 2010). Geleneksel medya karşısında sosyal medya, kullanıcı temelli bilgi üretimine imkân sağlaması, üretilen mesaj ve bilginin çok hızlı bir şekilde, uzun mesafelere ve büyük kalabalıklara en ekonomik şekilde ulaştırılması, geniş ve herkese açık kullanımı nedeniyle üretilen bilginin kullanıcılar arasında denetiminin hızla sağlanması (kısa sürede yalanlanması ya da doğrulanması) özellikleri ile algı yönetimi, kamuoyu oluşumu ve kamuoyunun yönlendirilmesi alanlarında güçlü etkilere sahiptir (Başıbüyük, 2014, 59-60).

Günümüzde kitle iletişim araçlarının çeşitlenerek artan bu gücü karşısında hedef kitleleriyle iletişim kurmak isteyen siyasal partiler ve adayların iletişim süreçlerini dijital ortamlarda da gerçekleştirmeleri önemli hale gelmiştir. Günümüzde siyasi aktörlerin sosyal medya mesajları, basın bültenleri, konuşmalar ve parti web siteleri gibi geleneksel bilgi sunma araç ve ortamlarının yerini almakta ya da basın kuruluşlarıyla olan haber ilișkisini büyük ölçüde değiştirmektedir (Hong ve Nadler, 2012). Gurevitch'e (2009: 167) göre dijital medya, analog kitle iletişim araçlarının güçlü etkisini azaltmıștır. Ancak bu değișiklikler bir "yerine geçme" sürecinden ziyade gelişmekte olan medya ortamı içerisinde gerçekleşen "yeniden yapılandırmanın", rol ve ilişkilerin "yeniden şekillendirilmesi" olarak yorumlanabilir. Vatandaşlar, medya ile etkileşime girmelerini, kendi içeriklerini ve bilgi dağıtımı için alternatif ağlar oluşturmalarını sağlayan masrafsız iletişim teknolojilerine erişim kazandıkça, önceleri editör ve yayımcıların ellerinde tuttukları bilgi akışını düzenleme tekeli de ortadan kalkmaktadır. Aracısız/filtresiz yönü ile sosyal medya ortamları, bireyin sadece oy kullanmakla yetinmeyip, siyasal iletişim sürecine aktif katılımını sağlayarak varlık göstermesine olanak tanıyan bir mecra olarak birey ve siyasetçi arasındaki iletişimi yakınlaştırmış; geleneksel iletişim hiyerarşisinin erişilmezliğini yıkmıştır. Bu süreçte birey, kendi duygu ve düşüncelerini paylaşmak suretiyle siyasilerle etkileşim kurmakta, bu sayede politik katılımını gerçekleştirmektedir. 
Öte yandan bu etkileşim, seçmenin algılarını siyasi aktörler tarafından yönetilmeye açık hale getirmiştir. Bu açıdan sosyal medyanın siyasi yönü olarak son yıllarda öne çıkan Twitter, yapısal unsurları ile algı yönetimi açısından önemli bir araçtır. Twitter, hızlı ve anındalık özelliği, az karakterle çok șeyi geniş kitlelere ulaștırma güdüsü ile son yıllarda politik içeriğin yayılmasında siyasiler tarafından yoğun biçimde tercih edilen bir sosyal medya platformudur.

Çalışmanın amacı, Twitter'ın yapısal unsurları doğrultusunda algı yönetiminde taşıdığı potansiyeli, siyasi partiler ve aktörlerinin kullanım pratikleri ve söylem biçimleri üzerinden analiz ederek ortaya koymaktır. $\mathrm{Bu}$ amaç doğrultusunda çalışmada, Twitter'ın hangi özellikleri ile kişilerin tutum ve algıları üzerinde etkili olduğu, örneklem olarak seçilen dört partinin lider ve adaylarının siyasal iletişim çalışmalarında, tweet kullanım pratiklerinin algı yönetimi çerçevesinde nasıl değerlendirildiği, örneklem olarak seçilen dört partinin lider ve adaylarının twitter hesaplarından yaptıkları paylaşımların içeriklerinin algı yönetimi çerçevesinde nasıl değerlendirildiği sorularına yanıt aranmıştır. Twitter'ın yapısal unsurları noktasında kullanım pratiklerinin ve bu mecrada üretilen söylem içeriklerinin algı yönetimi çerçevesinde değerlendirilmesi, sosyal medyanın siyasal iletişim ve algı yönetimindeki potansiyelinin ortaya koyulması açısından önemli görülmektedir. $\mathrm{Bu}$ yönüyle çalışma ayrıca Twitter kullanımı konusunda siyasi aktörlerin bilinçlendirilmesine yönelik farkındalık oluşturmayı hedeflemektedir. Örneklem amaca uygun örneklem yöntemi ile alınmıștır. 7 Haziran 2015 Genel Seçimlerine katılan dört partinin (AK Parti, CHP, HDP, MHP) genel başkanları ve MYK üyesi siyasi kişilerinin (24 kişi) 1 Mayıs - 10 Haziran tarihleri arasında paylaşılan 3757 tweeti nitel ve nicel içerik analizi yöntemi ile analiz edilmiştir. Araştırmanın sınırlılığını, örneklem için seçilen kişi hesapları ile ilgili yapılan kısıtlama oluşturmaktadır. AK Parti, CHP, MHP ve HDP'nin parti liderleri ile birlikte Merkez Yürütme Kurulu (MYK) üyeleri arasından en çok takipçi sayısına ve 500+ tweet sahibi olan 5'er kişinin tweet hesabı seçilmiştir. Araştırmanın diğer bir sınırlılığını ise, kişilerin kendi tweetleri ile ilgili yapılan sınırlama oluşturmaktadır. Retweetler bu araștırmada belirlenen kategoriler çerçevesinde analize tabi tutulmamıştır.

Yapılan literatür araştırmasında, algı yönetimi perspektifinden sosyal medyada yürütülen siyasal iletişim çalışmalarının analiz edildiği bir çalışmanın olmadığı gözlenmiştir. Sosyal medyada yapılan siyasal iletişim çalışmaları alanında pek çok çalışma yapılmış, ancak konu sosyal psikolojik açıdan algı yönetimi çerçevesinde ele alınmamıştır. Zira algı yönetimiyle ilgili yeterli akademik çalışmanın literatürde yer almadığı, yapılan çalışmaların ise daha çok uluslararası ilişkiler, dış politika ve güvenlik alanında yapıldığı görülmüştür. Ancak özellikle son yıllarda iç ve dış politikada yaşanan gelişmeler neticesinde algı yönetimi kavramı, medya ve siyaset sahnesinde sıklıkla kullanılan bir kavram haline gelmiştir. Buna karşın konu ile ilgili alanda yapılan çalışmalar oldukça az sayıdadır. Çalışmanın bu yönüyle alana katkı sağlayacağı düşünülmektedir.

\section{Algı Yönetimi}

Günümüzde insanlar her an pek çok içerik ve uyaranlara maruz kalmakta ve bunlara yönelik olarak tutum, kanaat geliștirmekte ve algı oluşturmaktadır. Bilgi veya iletinin hedef kitleye iletilmesi aşamasında pek çok değişken önemli rol oynamaktadır. Kitle iletişim araçları bu süreçte bilgi ve iletilerin biçim ve içerik olarak şekillendirildiği ve bireylere sunulduğu güçlü bir değişken olarak karşımıza çıkmaktadır. Bu kapsamda 
algı, algılama kavramlarını iletişim ve enformasyon temelinde anlamaya çalışmak çalışmamız açısından önem taşımaktadır.

Algı, kişinin çevresindeki nesneleri, olayları, ilişkileri duyu organları yoluyla anlamak, anlamlandırmak ve belli bir davranış ortaya koyması sürecidir (İnceoğlu, 2011, 86). Bir başka yoruma göre ise algı, beynin çeşitli duyulardan gelen bilgi karmaşası içinden anlamlı örüntüler yorumlamasıdır (Morris, 2002, 121). Erol Mutlu ise $(2012,16)$ algıyı şu şekilde tanımlamaktadır: "Duyularla alımlanan, beyin tarafından işlenen, bellekte depolanan ve fiziksel veya zihinsel bir tepke biçimi üreten enformasyon. İnsanın çevresindeki uyaranların ya da olayların ayırımında olması ve onları yorumlaması süreci". Buna göre dış çevreden gelen uyarıcıların duyu organlarımız üzerinde bıraktığı etki 'duyu', oluşan bu etkinin zihnimizde oluşturduğu şekle verilen anlam 'algı' olarak tanımlanmaktadır. Algıların alınma süreci ise algılamadır. Buna göre algı yönetimi algıdan başlayan, algılama ile devam bir süreci içermektedir (Türk, 2014, 15).

Algı yönetimi kavramı ise ilk defa Amerika Birleşik Devletleri Savunma Bakanlığı tarafından tanımlanmıștır. Her ne kadar 'algı ve algılama', psikolojinin temel kavramları olarak pek çok bilimsel çalışmada ele alınsa da, 'algıyı yönetmek', ilk kez ABD siyasi kararlarının ülkede ve tüm dünya kamuoyunda benimsenmesi için kullanılan bir yöntem olarak ortaya atılmıştır (Saydam, 2014, 78). ABD Savunma Bakanlı̆̆g'ndan yapılan tanıma göre algı yönetimi, "Kitlelerin duygu, düşünce, amaç, mantık, istihbarat sistemleri ve liderlerini etkileyerek, seçili bilgilerin yayılması ve/ veya durdurulması; bunun sonucunda hedef davranış ve düşüncelerinin hedefleyenin istekleri doğrultusunda yönlendirilmesidir." (http://enclopedia.thefreedictionary. com). Algı yönetimi genel olarak dört aşamadan oluşmaktadır: Hedef kitlenin dikkatinin çekilmesi; hedef kitlenin dikkatini kontrol altında tutmak için benzer bilgilerin sunulması ve paylaşılması; sunulan bilginin hedef kitlenin algılarıyla tutarlı hale getirilmesi, bilginin aynı pozisyonda kalması için iletişim kaynaklarında tekrar edilmesidir (Callamari ve Reveron, 15).

Algı yönetimi, hedef kitleyi etkileme amacı açısından bir çeşit propaganda olarak görülebilir. Ancak algı yönetimi, hedefler ve sonuçlar açısından propaganda ile benzerlikler taşısa da, araç ve yöntemler açısından farklılıklar barındırmaktadır. Siyasal iletişim ve propaganda alanında çalışmalar yapan Jean-Marie Domenach'a göre $(1995,17)$ propaganda, başlangıçtaki dinsel anlamından uzaklaşarak kişilerin kendi düşünce, görüş ve tutumlarını toplumlara ileterek onların tutum ve eylemlerini etkileme girișimleri olarak ifade edilmektedir. Propaganda özünde mesajların otoriter bir üslup ile tek taraflı ve yoğun olarak hedef kitleye aktarılmasıdır. Burada iletişimden çok tek taraflı mesaj gönderilmesi yani 'iletim' söz konusudur (Aziz, 2011: 15). Propaganda, bir mesajın tek yönlü ve dikey bir süreçte hedef kitleye dayatıldığı iletişim yöntemleri ile gerçekleşirken, algı yönetimi çok yönlü ve yatay bir iletişim sürecinde gerçekleşmektedir (Erol ve Ozan, 2014, 186-187). Garfield'e göre (2002: 33) algı yönetimi propaganda değildir, algı yönetimi, etkileşime dayalı bir iletişim sürecini barındıran, mesajların hedef kitlenin anlayabileceği şekilde (algı düzeyine uygun) biçimlendirilmesi ve bu biçimlendirilen mesajların, hedef kitlede istenilen tutum ve davranış değişikliğini oluşturmasıdır. Dolayısıyla propaganda ve algı yönetimi amaç etrafında değil, uygulamaları ekseninde birbirinden ayrılmaktadır. Başarılı bir algı yönetimi, hedef kitlenin değerleriyle uyum, hedef kitlenin kültürüyle uyum, beklentilerin üzerinde yaklaşım sergilemek, yalın olmak, sonuca 
odaklanmak, ölçümlemek, gerçeklere dayanmak, tekrar etmek, farklılaşmak, görselliği doğru yönetmek, düşüncelerden çok duygulara hitap etmek unsurlarından oluşmalıdır (Özer, 2002:175).

Algıyı önemli kılan husus, dış dünyayı ve nesneleri bize yansıyan şekliyle yorumlamamız dolayısıyla oluşmasıdır. Algı sürecinde birey, iki tür gerçeklik ile karşılaşmaktadır. Birincisi kendisinin birinci elden yaptığı gözlemler sonucunda ulaştığı gerçeklik, ikincisi ise kitle iletişim araçları yani medya yoluyla sunulan gerçekliktir (Türk, 2014, 28). Kitle iletişimi araçları tarafından iletilen mesajların, insanın kendi algılarıyla edindiği bilgiye oranla zihnindeki imgelerin ve gerçekliğine inandığımız sahte dünyanın oluşumundaki egemenliği dikkat çekmektedir (Çebi, 2003,112-113). Bu kurmaca süreçte algıların yönetilmesi amacıyla, karşı tarafın duygu, güdü ve tarafsız düşünme yeteneklerini etkilemekiçinile 'seçili' enformasyon gönderimi gerçekleştirilmektedir (Uğurlu, 2015, 297). Bu bakımdan bireyin dünyayı anlamlı bir resme çevirme çabası olan algılama sürecinin dış müdahalelere açılk bir süreç olması, birey dışındaki aktörlerin de karar sürecine müdahalesi için önemli bir fırsat yaratmaktadır. Bu süreçte hükümetler, elitler, medya ve diğer toplumsal gruplar bireylerin algılarını kontrol altında tutma çabası içerisinde birbirleriyle rekabete girmektedirler (Turan, 2014, 98). Bu süreçte insan aklı neyi nasıl algılar konusundaki sorular ve hedef kitlelere gönderilen mesajların içerik tasarımının nasıl yapılması gerektiği soruları sosyal bilimcilerin, siyasetçilerin ve diğer toplumsal aktörlerin paylaşılan ortak sorunları hale gelmiştir. Her siyasi rejim, iletişim kanallarını kullanarak vatandaşların görüşlerini etkileme ihtiyacı içerisinde varlık zeminini kuvvetlendirmektedir. Çünkü iktidar ve siyasal seçkinler hegemonyanın en iyi rızanın örgütlenmesi ile başarılabileceğinin farkındadırlar. Bu süreç ise algıların şiddet ya da zora başvurulmadan iletişim stratejileri ile inşa edilmesinin siyasal erk açısından gerekliliğini öne çıkarmaktadır. Coleman'a (2005, 10-12) göre, yurttaşlar ve siyasetçiler arasındaki kopukluğun giderilmesi için çift yönlü iletişim kurulması zorunluluk haline gelmiștir. Bu iletişim konuşma şeklinde, sürekli ve kalıcı nitelikte olmalıdır.

\section{Algı Yönetimi Aracı Olarak Sosyal Medya}

Algı ve tutum ortama ait etkenlerle etkileşim halinde davranışı meydana getirmektedir (Kağıtçıbaşı ve Cemalcılar, 2014, 134-135). Günümüzde siyasete ilginin kişisel ilgililik düzeyinin düşmesi karşısında insanlar kitle iletişim araçları kanalı ile kendilerine ulaşan siyasi iletiler üzerinde görece daha az düşünmektedirler. $\mathrm{Bu}$ nedenle seçim kampanyalarında tutum değişikliği, konu üzerinde derinlemesine düşünmekten ziyade kaynağın özellikleri gibi çevresel uyaranlardan daha çok etkilenmektedir (Milburn, 1998, 226). Bu noktada çevresel uyaran olarak bireyin algılarını biçimlendiren medyada hedef kitlelere yönelik olarak sunulan içeriklerin iletişimin gerçekleștiği ortamın veya aracın özelliklerine göre tasarımlanması önem taşımaktadır. Bireyler gündemdeki konuları değerlendirebilmek ve o konuya ilişkin algılarını oluşturabilmek amacı ile bilgiye ihtiyaç duymaktadırlar. Bu bilgiye ulaşmada ise, medyanın da içinde olduğu dış kaynakları kullanmaktadırlar. Bu veri akışının kontrolü ile kamuoyunun oluşumu sağlanarak algıların yönetimi amaçlanmaktadır (Turan, 2014, 101).

Medyanın çevresel uyaran olarak bireysel ve toplumsal algllama üzerindeki gücü açısından içinde bulunduğumuz yüzyıl yeni iletişim teknolojilerinin kitlelere 
sunduğu farklılıklara tanıklık etmektedir. Yeni medya iletişim teknolojilerinin günlük hayat pratiklerimiz içerisinde yerini alması ve dijital okuryazarlığın artması ile siyasal iletişim çalışmalarında kullanılan geleneksel yöntemlerin dönüşümü gerçekleşmekte, buna bağlı olarak ise siyasi aktörlerin de hedef kitlelerine yönelik olarak usul ve pratiklerinin değişimi önemli hale gelmektedir. Sosyal medyanın filtrelenmemiş ve kişiselleştirilmiş yönü, bilgiye erişimin zaman ve uzamdan bağımsız bir şekilde kolay, hızlı ve ucuz bir hale gelmesi, bireylere konu, olay ya da kişi ile ilgili çoklu kaynak özelliği sunması, iletinin kullanıcılar arasındaki yayılımı ve etkileşimli iletişime olanak sunması algı yönetimi açısından mesajı etkili kılmakta ve bu sayede siyasal iletişim çalışmaları açısından geleneksel medyaya kıyasla farkındalık oluşturmaktadır.

Geleneksel medyanın seslendiği kitlelere karşılık yeni iletişim teknolojileri, sosyal ağlarla birbirine bağlanan örgütlü kitle iletişim biçimini ortaya çıkarmıştır. $\mathrm{Bu}$ süreçte birey sosyal ağlar aracılığıyla sanal kalabalıklara dâhil olmaktadır. Böylelikle kitleler üzerinde kurulan siyasal meşruiyet yerini sosyal ağlar aracılığıyla birbirine bağlanan, her bir kullanıcının bireysel olarak aktif konumlandırıldığı ve bu şekilde kamuoyunun zihnini şekillendiren yeni iletişim biçimine bırakmıştır. Toplum içerisindeki her bir bireyin güncel hayata ilişkin her türlü yeniliğeve bu paraleldeki her tür habere karşı algısı daima açıktır. Sosyal medyanın kişiye ait, dışa açık ama hareket kabiliyeti yönünden özel bir alan oluşturması, aynı kişiye aynı zamanda söz hakkı da veriyor olması bu algı açıklığını daha da arttıran önemli unsurlardır (Yıldız, 2013, 56). Bu anlamda online dünyada algıların yönetilmesine zemin hazırlayan, süreci kolaylaştıran, gerek kullanıcının gerekse mecranın kendi yapısından kaynaklanan etkileri şu şekilde sıralamak mümkündür (Uğurlu, 2015, 302): Kullanıcı artık pasif bir özne değil, eklektik yapının içerisinde içeriği dönüştürüp, kişiselleștirebilmekte, enformasyon saniyelere indirgenebilecek zaman dilimi içerisinde küresel boyuta yayllabilmekte, salt var olan üzerinden değil; gösterilmeyen/gizlenen üzerinden mesaj manipüle edilebilmekte; karşı tarafın tutum ve tarafsız düşünme yetenekleri teşhis edilerek eyleme geçmeye yönelik harekete geçirilebilmektedir.

Kitle iletişim araçlarıyla tutum değişikliği oluşturma önündeki başlıca engeller; bireyin farklı ya da karşıt bilgilere yeterince hedef olmaması ve yüksek düzeyde bağlanılmış tutumların değişikliğe karşı dirençli olması durumudur (Taylor ve diğerleri, 2012, 509). Seçici hedef kitleye ulaşımın böylesine zorlaştığı bir ortamda, alternatif bir araç olarak ortaya çlkan sosyal medya, doğrudan iletişim süreci ile bireylerin tutum ve algılarını etkileme ya da değiştirme konusunda etkili ve kişiselleştirilmiş stratejiler gerçekleştiren araç ve uygulamalarını kullanıcılarına sunmaktadır. Bir anlamda butik stratejiler ile seçici hedef kitleye ulaşmak daha kolaylaşmış, siyasal tutumlar gibi dirençli olan tutumlara karşı sosyal medyanın kişiye özel etkileşimli yapısı önem kazanmıştır.

Sosyal medyanın etkileşimli iletişime imkân vermesi, bireyi içinde yaşadığı toplum ve erk sahipleri ile ilişkilerinde edilgen (pasif) olmaktan çıkarıp, etken (aktif) bir konuma yükseltmesi, birey-aile, birey-toplum, birey-devlet ilişkilerinin geleneksel kodlarını bozmuş ve bu ilişkileri birey merkezli olarak yeniden şekillendirmiştir. Sosyal medya, insanlar için haberleşme ve iletişim aracı olmanın ötesine geçerek, bir sosyalleşme ve kendini ifade edebilme, içinde yer aldığı her düzeydeki örgütlü yapılara katılma platformlarına dönüșmüștür (Eren ve Aydın, 2014, 198). Kendini ağ toplumunda yeni iletişim teknolojileri ile konumlandıran bireyler, sosyal medya 
ortamlarının ortaya çıkardığı koreografik yapı içerisinde bir araya gelerek siyasal, ekonomik ve kültürel alanlarda bilgi paylaşımında bulunmaktadır. Sosyal ağ topluluklarının büyümesi daha büyük bir arkadaş grubu, daha çok takipçi ve bağlantı anlamına gelmektedir. Sosyal medya üyelerinin oluşturduğu irili ufaklı topluluklar sosyal medya gruplarını oluşturmaktadır. Bu bağlamda yeni iletişim teknolojileri ile iletişimin gözbebeği haline gelen sosyal medya mecraları kullanıcılarını gruplamaya eğilimli yapılar olarak konumlanmaktadır (Akyazı ve Aslan, 2013, 182). Diğer bir deyişle sosyal ağ siteleri, bir yandan kullanıcıyı bireyselleştiren, diğer yandan farklı sosyal çevrelerden arkadaşlarını bir araya getirdiği bir ağ işlevi görerek kullanıcıya bir gruba aidiyet duygusu yaşatan bir iletişim aracı olarak işlev görmektedir (Şener, 2010). Kitle içerisinde yer alan ve grubun psikolojisi ile bütünleşmiş birey kolektif bir ruh yapısına büründüğünden, tek başına yapacaklarından, düşüneceklerinden, duyacaklarından farklı hissetmekte ve düşünmektedir. Le Bon'a göre (2014, 27-29) bunun sebebi grup içerisinde bulunan bireye çokluğun verdiği coşku duygusudur. $\mathrm{Bu}$ algı bireyin tutumlarının oluşumu ve değişiminde önemlidir.

Le Bon $(2014,127)$ kitlelere sunulan mesajların yayılımı için, bireylerin aynı yerde toplu bir halde bulunma şartı taşımadığını söylemektedir. O'na göre kitlelere sunulan fikir ve inançlar özellikle bulaşma mekanizması ve değerlendirme mekanizması ile yayılmaktadır. Bu süreci etkili kılan, tekrarın farklı kaynaklardan yapılmasıdır. Sosyal medya ortamlarının diğer kitle iletişim araçlarından farklı olan en önemli özelliklerinden anındalık özelliği, paylaşılan iletilerin geniş bir yayılıma girmesine imkân vermektedir. Her kullanıcının kendi sosyal çevresi olduğu düşünüldüğünde ise katlanarak artan bir yayılım söz konusu olmaktadır. Sunulan mesajların bireyler arasında hızlı yayılımı, bu yayılım ile bireyden bireye bulaşan mesajın etkileme gücü ve içeriğe ilişkin kullanıcı temelli değerlendirmeler algıların yönetiminde önemli rol oynamaktadır. Lynch'a göre (2002) toplumdaki bireyler arasında fikirlerin yayılmasında temel olarak üç faktör etkilidir (Aktaran: Başıüyük, 2014, 58). İlk sırada, mesajın kolaylıkla yayılması ve basitleștirilmesi gelmektedir. İkinci unsur, mesajların anlaşılabilir olmasıdır. Fikirlerin toplumda yayılmasını etkileyen üçüncü faktör de mesajın uzun süreli ve çok sesli olarak dile getirilmesidir. Sosyal medya mecraları bu anlamda önemli rol oynamaktadır. Le Bon'a göre $(2014,123-125)$ 'iddia, tekrar ve yayılma' kitleler üzerinde telkin yöntemleri arasındaki güçlü yöntemlerdir. Sade bir içeriğe sahip anlaşılır bir iddia, kitlelerin ruhuna bir fikri yerleștirmek için en etkili araçtır. İddianın etkili olabilmesi için ise mümkün olduğu kadar aynı kelimelerle tekrarı önemlidir. İddia olunan şey, tekrar edilmek suretiyle ispat edilmiş bir hakikat gibi kabul olunarak zihinlere yerleşmektedir. Nitekim böyle bir durumda iddiaların kimin tarafından ortaya atıldığı unutulacak ve tekrarlanan mesajlara inanılacaktır. Twitter'ın sınırlı karakterden oluşan basit biçimi kısa mesajların hızlı bir şekilde yayınlanmasını sağlarken, kişisel ve etkileşimli özellikleri seçmenleri geleneksel iletişim araçlarına göre daha çekici kılmaktadır (Kapko, 2016).

Popüler kültürden giderek daha fazla etkilenen siyasal iletişimde tarz ve sunum gün geçtikçe daha da önemli bir hal almaktadır. Alman sosyolog Ulrich Beck (1994) toplumların içerikten ziyade görüntüye ilgi gösterdiklerini, bu bağlamda siyasi bir mesajın görünüm, imaj ve sunumunun en az içeriği kadar önemli olduğunu söylemektedir (Aktaran: Lilleker, 2013, 33). Bu noktada sosyal medya sahip olduğu özellikleri ile iletişimin sanal ortama taşınmassından çok öte bir misyona sahiptir. Sosyal medyanın bireylere sunmuş olduğu yazı, fotoğraf, ses, video ve her türlü bilgi 
ve belgeye ulaşım imkânları iletinin içeriğini ve tasarımını etkilemekte, bu sayede halkla ilişkiler, pazarlama, siyaset başta olmak üzere tüm alanlarda istenen algılara yönelik kampanya tasarımları oluşturulmaktadır. Sosyal medyanın multimedya yapısı ve hipermetinsellik özelliği sayesinde bireylerin simgesel, görsel, duygusal ve seçimleyici algılarının tümüne etki etme durumu söz konusu olmakta, böylelikle bireylerin algılarına çok yönlü ulaşma imkânı artmaktadır. Sosyal ağların görsel kültürle olan sıcak ilişkisi, görsel materyallerin teşhirine uygunluğu, paylaşıldığından kısa bir süre içerisinde kişilere yayılımı, enformasyonun imajlarla donatılıp dikkat çekicilik sağlamasını beraberinde getirmektedir (Uğurlu, 2015, 301).

Günümüzde internet ve sosyal medyanın aktif bir biçimde kullanımı kamusal alanı genişletmekte, olayların ve amaçların arka planının toplum tarafından daha iyi anlaşılmasına imkân tanımaktadır (Gökçe, 2012, 48). Bu mecraların metinler arası erişim imkânı tanıyan hipermetinsellik özelliği ve bireyin ihtiyaç duyduğu her türlü bilgi ve belgeye kolaylıkla erişimini sağlayan dijitallik özelliği sayesinde iletinin arka planına yönelik bireyin yönlendirilmesinin daha kolay gerçekleștiğini söylemek mümkündür. Sosyal medyanın bu yönü iletinin kapsamının genişlemesine, bireyin iletinin ardyöresine ilişkin bilgi/belgelere erişimini kolay kılmaktadır. Mesajın tek yanlı sunulması, kaynağın alıcıyı ikna sürecinde sadece yandaşı olduğu görüşü destekleyen iletiler göndermesi şeklinde olmaktadır. Mesajın çift yanlı olarak sunulması ise kaynağın kendi görüşünü desteklerken, alıcıya karşıt görüşten de söz etmesini, hatta bazen kendi lehinde karşılaştırmalar yapmasını ifade etmektedir. (Doğan, 2013, 19). Mesaj içeriğinde kişi karşıt görüşe de yer verdiğinde ileride karşılaşılabilecek anti-propagandaya karşı görmezden gelme durumu kişiye aşılanmış olmaktadır (Erdoğan ve Alemdar, 2002, 110). Bu durumun siyasal iletişim çalışmalarında siyasilerin propaganda çalışmaları açısından ne denli önemli olduğu açlktır.

Medyada oluşturulan iletinin tasarımlanması sürecindebireylerin tutum vealgılarının oluşmasına etki eden önemli bir diğer argüman da, anlatı inşa etme yöntemi olan 'çerçeveler'dir. Çerçeveler, sorunları tanıyan, değerlendiren ve reçete eden iletişim araçlarıdır (Entman, 1993). Çerçeveler, toplumsal meseleleri düzenleyici fikirler ya da temalar olarak anlamayı kolaylaștırmak ve zenginleştirmek, için tasarlanan bilişsel kısayollardır (Lilleker, 2013, 111-113). Bu etiketler, karşı tarafta yaratılmak istenen algının oluşma sürecinden rızanın tesisine kadar ki süreçte algı yönetene oldukça elverişli bir ortam sunmaktadır. (Uğurlu, 2015, 304). Siyasiler Twitter'da oluşturulan etiketler (hashtagler) aracılığıyla konu ya da olaya ilişkin aracısız/ filtresiz söylem üretmekte ve bu sayede tutum ve algıları çerçeveleme yoluyla doğrudan etkileme fırsatına sahip olabilmektedirler.

Siyasilerin geleneksel mecralara göre sosyal medyada kişiselleştirilmiş kampanya yürütmeleri, üslup biçimlerini geleneksel mecralara göre daha önemli hale getirmektedir. Richards (1994), siyasal söylemin seçmenin gündelik yaşantısına ait bir şeyler içermesi, siyasilerin duygularını içermesi ve zor ve çelişkili konular yerine, toplumun umutları, korkuları ve kayglarıyla ilgilenmesi durumunda duygusallaşabileceğini söylemektedir. Lilleker da $(2013,108)$ siyasilerin bilgi paylaşımında bulunurken de seçmenin duygusal yönüne hitap edebileceklerini söylemektedir. Bu bakımdan sosyal medya ortamları hem farklı iletişim türlerini birleştiren hem de sözlü, yazılı ve görsel kültürün özelliklerinin etkileşimli bir şekilde varlığını sürdürdüğü ortamlardan biridir (Yeşilyurt, 2015, 82). Ong'a göre 
(2014) sözlü kültürün psikodinamiği, insanın güncel konulara dair konuşmalarının yalın, basit, açı cümleler yardımı ile sunulmasına, bellek gücüne dayanan yapısı ile katılımcı ve duygudaş bir zeminde değişmeden tekrarlanan sözcüklerin çok sayıda kullanımına bağlıdır. Ayrıca geleneksel toplumlarda hala varlığını sürdüren karşılıklı atışma sanatının temelini oluşturan yarışmacı, kavgacı ve ikna etmeye yönelik sözlü tavır, bu kültürün en önemli özelliklerinden birini oluşturmaktadır. Baldini de (2000: 15) sözlü kültürün taşkın ve katılımcı yanına dikkat çekmektedir. Sözlü kültür insanları yazılı kültür insanlarından daha sıcak ve gürültülü izleyici ve dinleyici kalabalıkları oluştururlar, genellikle konuşan kiși tarafından sürüklenir, onunla özdeşleşirler. Bu bakımdan sosyal medyanın karakteristik yapısı, sözlü kültürün özelliklerini kendi ortamına taşımıştır.

Twitter'ın sınırlandırılmış bir ileti yapısına sahip olması, yazılı iletilerin daha çok sözlü kültür unsurları kullanımını ve konuşma dili özelliklerini içermesine sebep olmaktadır. Kültürel inanışlar, efsaneler, hikâyeler, streotipler, halk kahramanları, atasözleri, deyim, özlü sözler, iletinin gücünü artırarak halk kitlelerinde heyecan ve çeşitli duygular yaratmak için kullanılmakta, bu unsurlarla oluşturulan ileti akılda kalıcılık, etkililik açısından tutum ve algıları etkileyen önemli ikna bileşeni olarak görülmektedir. Richards (1994) siyasal iletişim sürecinde lider ya da adayların, siyasi iletilerini günlük yaşamın duygusal anlatımı içinde ifade etmesi gerektiğini, bunu yaparken de halkın konuştuğu dile yakın bir dil kullanılmasını önermektedir. Kişiselleştirilmiş sosyal medya mecraları diğer kitle iletişim araçlarına kıyasla iletilerde, duygusal öğelerin daha fazla kullanıldığı, yalın ve kısa iletişim biçimiyle genel olarak konuşma dilinin hâkim olduğu ortamlar olarak şekillenmiştir. Hatta sosyal medyanın bu yapısı kullanıcıların duygu imleri (;), :) kullanarak konu/olay karşısında nasıl bir duygu hali içerisinde oldukları ile ilgili bir yanılsamayı sundukları konuşma mimarisini ortaya çıkarmıştır.

\section{Twitter'ın Yapısal Unsurları ve Algı Yönetimi}

Sosyal medya uzamlarından biri olan Twitter, genele ulaşma çabasında olan, hızlı ve dinamik bir yapıya sahip, az karakterle çok şey paylaşılan bir sosyal ağ olarak son yıllarda siyasetçiler, gazeteciler ve bireyler tarafından hızla artan oranda kullanımıyla dikkat çekmektedir. Yapılan çeşitli araştırmalarda siyasetçilerin Twitter'ı bilgilendirme, etkileşim, hareketlilik ve kampanya ile bütünleşme amacıyla kullandıkları ortaya çıkarılmıştır (Lilleker ve diğerleri, 2011). Bu saptamaya göre Twitter'ı bilgilendirme amaçlı kullanımda siyasi aktörler, yurttaşlar ve gazeteciler Twitter'dan bilgi toplarlar. Etkileşimde bu bilgileri retweet veya etiket yoluyla kendi takipçileri ile paylaşırlar ve bu sayede bilginin dolaşımını hızlandırarak görünürlügünü artırırlar. Hareketlilikte ise siyasetçiler seçmenleri miting, etkinlik gibi eylemlere katılamaya davet ve teşvik ederler. Bütünleşmede ise siyasetçilerin ürettiği çevrimiçi siyasal enformasyonun kullanıcılar tarafından paylaşılması ve yurttaşların çevrimdışı siyasal etkinliklerle bütünleşmesi ifade edilmektedir.

Twitter'daki bu etkileşim "takip" fonksiyonuyla sağlanmaktadır. Kullanıcının bu gücü, kişinin siyasal sürece katılımını kolaylaştırmakta, bir anlamda kullanıcılarının politize olmalarına destek olmaktadır. Bireylerin takip ettikleri siyasi aktörlerle kurdukları sanal ilişki, bireyin tutum ve algılarını etkilemektedir. Bu anlamda siyasal aktörlerin takipçi sayısının yüksek olması, kararsız seçmenlerin tutumlarını olumlu yönde etkileyen bir faktördür (Keskin ve Sönmez, 2015, 349-350). Kaynakla fiziksel yakınlığın olması da iletişim kaynağının sevilen ve beğenilen olma durumunu 
etkilemektedir (Coşkun, 2013, 140-141). Bu açıdan yüzyüze iletişimin online dünyada kurulan simülasyonu mesafeleri yakınlaștırarak bu algıyı olușturmaktadır.

Birey ve siyasal mekanizmalar arasında etkileșimi sağlayan Twitter, @ kullanıcı (@user), @bahsetme (@mention), @yanıt (@reply), iletiyi aynen tekrar etme (retweet), beğeni (favori) ve \#etiket (\#hashtag) olarak belirlenen yapısal unsurlara sahiptir. Kullanıcının takip ettiği diğer bir kullanıcının tweetini retweet ederek aynen paylaşması, favori yaparak beğenmesi içeriğin görünürlüğünü artırmaktadır. Bu durum aynı zamanda tweetin onaylanma, kabul görme biçimi olarak görülebilir. Bir tweetin retweet edilme ve favori edilme oranı ne kadar yüksek ise kitleler üzerindeki etkisi de o oranda güçlü olarak gerçekleşmektedir. Yapılan çalışmalarda bu mecralarda viral yayılım gösteren bilgi ve söylentilerin dağılım sayısı arttıkça daha fazla güvenilir hale geldiği, belirli bir zaman ve dağılım eşiğini aştıktan sonra ise bilgi ve söylentilerin toplumda doğru olarak kabul gördügü gözlenmiștir (Ratkiewicz, 2011: 298). Ayrıca araştırmalar güçlü partizanlığa sahip kullanıcıların paylaşmaya değer olduğunu düşündükleri içeriği yayma olasılıklarının daha yüksek olduğunu göstermektedir (Lee ve Song, 2017).

Twitter'ın @bahsetme (@mention) özelliği ise doğrudan iletişim ve karşılıklı diyalog kurma avantajı sağlayarak etkileşimi artırmaya yönelik hizmet den bir uygulamadır. Siyasiler tarafından henüz çok fazla kullanılmayan Twitter'ın bu özelliği, esasında kişiye özel iletişim ve ikna açısından son dereceönemlidir. @etiket (@hashtag) kullanımı ise bir konuyu çerçeveleyerek kamusal alanda tartışmaya açmak amacıyla kullanılan bir özelliktir. Oluşturulan etiket altında paylaşılan tüm içerikler bir araya toplanarak kategorize edilmektedir. Ayrıca konunun etiketlenerek daha çok kişiyle etkileşim kurulmasına olanak tanıyan hashtaglerin kullanımı ile geleneksel medyadaki gündem başlıklarına paralel ya da siyasi parti ve adayların önemsedikleri alternatif bir konu gündeme taşınabilmektedir. Böylece hashtag kullanımı ile kullanıcı, önemli gördüğü bir konu hakkında kișisel gündem oluşturabilmekte ve belirlediği konu hakkında kamusal bir konuşma başlatabilmektedir. Bu bakımdan çerçeveler, bireylerin olayları ve bilgileri istendik biçimde belirleme, algılama, teşhis etme ve adlandırmasına olanak sağlayan araçlar olarak gerçeklik algısını yönetirler (Turan, 2014, 104).

Yukarıda belirtilen yapısal özellikler, Twitter'ı sürekli enformasyon akışının ve diyaloğun sürdüğü bir sosyal paylaşım alanı haline getirmekte bu durum ise siyasi aktörlere iletişim çalışmalarında önemli derecede katkı sunmaktadır (Tosuner, 2015, 134). Diğer yandan kullanıcı türevli yapısıyla iletinin hızlı akışı gündemin kısa aralıklarla değişmesine imkân tanımaktadır. Twitter'ın hız faktörü; Twitter'ın "olay yerinden bildirme" algısını kuvvetlendiren bir mecra olarak tanımlanmasını sağlamakta, enformasyonun iletilmesi ve bunun üzerinden zihinleri kontrol edebiliyor olmasını da kuvvetlendirmektedir (Uğurlu, 2015, 303). Twitter'ın önemli özelliklerinden biri de sosyal medyanın bağlantılılık özelliğinden beslenen URL/link kullanımıdır. Bu sayede iletiye ait konu, olay ya da kişi ile ilgili çevrimiçi çoklu kaynak imkânı eş zamanlı olarak kullanıcıya sunulmaktadır. Bireyin iletinin ardyöresine ait bilgi/belgelere erişimi böylelikle mümkün kılınmaktadır. Bu durum, bireyin mesaj/ ileti hakkında daha fazla veriye ulaşılmasına imkân vererek mesajın ikna ediciliğini artırmaktadır. Böylece sınırlı karakter kullanımının ötesine geçilebilmektedir. Bu durum, kullanıcıya iletisinin kapsamını genişletme imkânı sunmasının yanında ayrıca iletinin, bağlantıların kullanıcılar arasında yayılmasını da kolaylaştırmaktadır. 


\section{Metodoloji ve Bulguların Analizi}

Çalışmada nicel ve nitel içerik çözümlemesi kullanılmıștır. Bu çalışmanın nicel içerik çözümlemesi, Klaus Bruhn Jensen'in $(2011,48)$ internet araştırmalarında temel olarak kabul ettiği nicel metotlardan biri olan siyasal enformasyon kaynaklarının içerik çözümlemesine dayanmaktadır. Jensen $(2011,52)$, internetin özel bir analitik nesne olduğu ve kendi verisini kendisinin ürettiğini ve internet çalışmalarında nitel ve nicel içerik çözümlemesinin birlikte kullanıldığını belirtmektedir. Bu yöntem yani nicel yöntemlerle birlikte nitel yöntemlerin de kullanıldığı karma tekniği benimseme yaklaşımı, araştırmacıya metnin ardyöresinde üretilene/kurulana bakması anlamında yardımcı olmaktadır (Çomu, 2014, 43). Örneklem amaca uygun örneklem yöntemi ile alınmıştır. Dört siyasi partinin genel başkanları ve MYK üyeleri örnekleme dâhil edilmiștir. Bu kișilerden 500+ tweet sahibi olan ve en fazla takipçisi olan kişiler nitel ve nicel içerik analizi için seçilmiştir. Her partinin MYK üyeleri arasından en fazla takipçiye sahip 5'er kişi 2015 Genel seçimleri için kesin aday listelerinin açıklandığı 07 Nisan 2015 tarihinde belirlenmiştir. Toplamda dört parti ve 24 kullanıcının tweetleri 01 Mayıs - 10 Haziran tarihleri arasında incelenmiştir. Tweetler web ara yüzü kullanılarak pdf formatına yazdırılarak kayıt edilmiştir. Örneklem olarak özellikle partilerin kurumsal hesapları değil, partili kişi hesaplarının seçilme sebebi ise kişiselleştirilmiş mecra olan sosyal medya platformlarında siyasi aktörlerin/liderlerin kendi kişiselleștirilmiş kampanyalarını değerlendirebilmektir. Çalışmada kullanıcıların yazılı, görsel ve işitsel olarak sunduğu iletiler aracılığıyla algı yönetimi yapmak üzere geliştirdiği içerik ve söylem biçiminin tweetler üzerinden analiz edilmesi ve böylece parti düzeyinde genel söylem biçimine ulaşılması hedeflendiğinden sadece kullanıcıların kendi yazdıkları özgün tweetleri ele alınmıștır. Retweetler bu araştırmada belirlenen kategoriler çerçevesinde analize tabi tutulmamıştır.

Araştırmada kullanılacak kodlama birimleri üç kişilik ekip tarafından geliştirilmiş ve kodlama birimlerini tanımlayan kod yönergesi ${ }^{1}$ oluşturulmuştur. Kodlama cetvelinde yer alan birimlerin işleyip işlemediğinin sınanması için ise pilot uygulama veri tabanı üzerinde yapılmıştır. Bu pilot uygulama neticesinde kodlama sürecinde ortak bir çerçeve sağlanarak kodlama cetvelinin uygunluğu ve tutarlılığının sağlanması için kodlayıcılar arasında bilgi alışverişi gerçekleştirilmiştir. Verilerin belirlenen konu başlıklarında analizleri alınmıștır.

Örneklem olarak ele alınan tweet adresleri, kişiler ve partileri ile bilgiler aşağıda tablolaştırılmıştır:

Tablo 1: Kayıtlanan Hesaplar, Kişiler ve Partileri ${ }^{2}$

\begin{tabular}{|l|c|c|l|}
\hline \multicolumn{4}{|c|}{ Adalet ve Kalkınma Partisi (AK Parti) } \\
\hline Adı Soyadı & Twit & Takipçi & Twitter Adresi \\
\hline Ahmet Davutoğlu & 1.469 & 2.866 .384 & https://twitter.com/Ahmet_Davutoglu \\
\hline Süleyman Soylu & 3.828 & 74.170 & https://twitter.com/suleymansoylu \\
\hline Mustafa Şentop & 2.213 & 125.859 & https://twitter.com/MustafaSentop \\
\hline Yasin Aktay & 12.922 & 115.625 & https://twitter.com/yaktay \\
\hline Haluk İpek & 1.454 & 88.602 & https://twitter.com/halukipek06 \\
\hline Mahir Ünal & 2.039 & 100.752 & https://twitter.com/mahirunal \\
\hline
\end{tabular}




\begin{tabular}{|l|c|c|l|}
\hline \multicolumn{4}{|c|}{ Cumhuriyet Halk Partisi (CHP) } \\
\hline Adı Soyadı & Twit & Takipçi & Twitter Adresi \\
\hline Kemal Kılıçaroğlu & 2.277 & 2.846 .162 & https://twitter.com/kilicdarogluk \\
\hline Mehmet Bekaroğlu & 27.864 & 152.214 & https://twitter.com/MBekaroglu \\
\hline Ahmet Haluk Koç & 3.869 & 166.871 & https://twitter.com/Chphalukkoc \\
\hline Şafak Pavey & 866 & 1.164 .679 & https://twitter.com/safAK Partiavey \\
\hline M.Sezgin Tanrıkulu & 3.662 & 179.878 & https://twitter.com/MSTanrikulu \\
\hline Gürsel Tekin & 3.604 & 525.260 & https://twitter.com/gurseltekin34 \\
\hline & Halkların Demokratik Partisi (HDP) \\
\hline Adı Soyadı & Twit & Takipçi & Twitter Adresi \\
\hline Selahattin Demirtaş & 1.181 & 652.073 & https://twitter.com/hdpdemirtas \\
\hline Figen Yüksekdağ & 2.792 & 55.640 & https://twitter.com/FigenYuksekdag \\
\hline Ayhan Bilgen & 1.6630 & 47.844 & https://twitter.com/ayhanbilgen \\
\hline Gülser Yıldıım & 1.588 & 27.194 & https://twitter.com/yildirimgulser \\
\hline Hüda Kaya & 772 & 21.197 & https://twitter.com/HudaKaya777 \\
\hline Meral Danış Beştaş & 4.916 & 68.436 & https://twitter.com/meraldanis \\
\hline \multicolumn{5}{|c|}{ Milliyetçi Hareket Partisi (MHP) } \\
\hline Adı Soyadı & Twit & Takipçi & Twitter Adresi \\
\hline Devlet Behçeli & 2.397 & 1.645 .513 & https://twitter.com/dbdevletbahceli \\
\hline Şefkat Çetin & 2.300 & 67.315 & https://twitter.com/sefkatcetin \\
\hline Mevlüt Karakaya & 3.903 & 39.459 & https://twitter.com/KarakayaMevlut \\
\hline Yıldırım Tuğrul Türkeş & 2.296 & 69.929 & https://twitter.com/TugrulTurkes \\
\hline Ruhsar Demirel & 5.793 & 39.982 & https://twitter.com/ruhsardemirel \\
\hline Zühal Topcu & 2.806 & 50.580 & https://twitter.com/profzuhaltopcu \\
\hline
\end{tabular}

\subsection{Partilerin ve Liderlerin Tweet ve Retweet Kullanımı}

Araştırma kapsamında örneklem olarak ele alınan ve analizi yapılan tweetler, kullanıcıların kendi yazdıkları özgün tweetleridir. Ancak retweet kullanımı, kişi/ parti siyasal iletişim çalışmalarında kullanıldığından örnekleme dâhil olan partilerin ve liderlerin retweet kullanım oranları kendi özgün tweet kullanım oranları ile karşılaştırmalı olarak Tablo 2'de verilmektedir:

Tablo 2: Partilerin Tweet ve Retweet Kullanımı Sayıları

\begin{tabular}{|l|c|c|c|}
\hline Parti & Tweet Sayısı & Retweet Sayısı & Toplam \\
\hline AK Parti & 1.290 & 587 & 1.877 \\
\hline CHP & 1.101 & 269 & 1.370 \\
\hline HDP & 457 & 755 & 1.212 \\
\hline MHP & 909 & 201 & 1.110 \\
\hline Toplam & 3.757 & 1.812 & 5.569 \\
\hline
\end{tabular}

Partilerin tweet kullanım yoğunlukları arasında belirgin farklılık görülmektedir. Örneklem olarak alınan 3.757 tweetin \%35'ini AK Parti, \%29'unu CHP, \%24'ünü MHP, \%12'sini HDP oluşturmaktadır. AK Parti'li kullanıcılar arasında en fazla tweet gönderen kişi 480 tweet ile Süleyman Soylu olurken, CHP'li kullanıcılar arasında en fazla tweet gönderen kiși 455 tweet ile Haluk Koç olmuştur. MHP'li kullanıcılar arasında ise 298 tweet ile Ruhsar Demirel, HDP'li kullanıcılar arasında ise Meral Danış Beştaş 178 tweet ile en fazla tweet gönderen kişi olmuştur. Belirtilen tarih aralığında retweet özelliğini en çok kullanan parti 755 retweet ile HDP'dir. Retweet paylaşımında ikinci parti, en fazla özgün tweete sahip parti olan AK Parti'dir. 3.sırada 
CHP 269 retweet kullanımı ile yer alırken, en az retweet kullanımı 201 retweet ile MHP'de olmuştur. Partiler arasında kendi özgün tweet kullanımı en az olan parti de HDP'dir. HDP dışındaki tüm partilerin retweet kullanımı özgün tweet kullanımından belirgin oranda düşüktür.

Tablo 3: Liderlerin Tweet ve Retweet Kullanımı Sayıları

\begin{tabular}{|l|c|c|c|}
\hline Parti Lideri & Tweet Sayısı & Retweet Sayısı & Toplam \\
\hline Ahmet Davutoğlu & 86 & 12 & 98 \\
\hline Kemal Kılıçdaroğlu & 62 & 22 & 84 \\
\hline Selahattin Demirtaş & 18 & 1 & 19 \\
\hline Devlet Bahçeli & 44 & 0 & 44 \\
\hline Toplam & 210 & 35 & 245 \\
\hline
\end{tabular}

Liderlerin tweet kullanım oranları, parti grubu olarak tweet kullanım oranları ile paralel bir yapı sergilemektedir. Liderlerin tweet sayıları arasında anlamlı bir fark vardır. Belirtilen tarih aralığında parti liderlerinin (genel başkan veya eş başkan) genel olarak retweet kullanım sayıları ise oldukça düşüktür. MHP lideri Devlet Bahçeli'nin hiç retweet paylaşmadığı, Selahattin Demirtaş'ın 1 retweet kullanması dikkat çekicidir. Figen Yüksekdağ'ın ise 31 retweet paylaştığı, AK Parti, Genel Başkanı Ahmet Davutoğlu'nun 12, Kemal Kılıçdaroğlu'nun ise 22 retweet paylaştığ görülmüştür.

\subsection{Partilerin ve Liderlerin Tweetlerinin Retweet ve Favori Yapılması}

İleti/mesajın aynen tekrarlanmak suretiyle yayılımı algı ve tutumların oluşumu açısından önemlidir. Bu noktada twitterin önemli bir yapısal unsuru olan retweet kullanımı algı yönetimi açısından değerlendirilmiştir.

Tablo 4: Partilerin Tweetlerinin Ortalama Retweet ve Favori Sayıları

\begin{tabular}{|l|c|c|c|c|c|}
\hline Parti & Tweet Sayısı & $\begin{array}{c}\text { Toplam } \\
\text { Retweet Sayısı }\end{array}$ & Toplam Favori Sayısı & $\begin{array}{c}\text { Ortalama } \\
\text { Retweet Sayısı }\end{array}$ & $\begin{array}{c}\text { Ortalama } \\
\text { Favori Sayısı }\end{array}$ \\
\hline AK Parti & 1.290 & 163.721 & 208.656 & 126,92 & 161,75 \\
\hline CHP & 1.101 & 150.574 & 174.257 & 136,76 & 158,27 \\
\hline HDP & 457 & 157.270 & 193.582 & 344,14 & 423,59 \\
\hline MHP & 909 & 160.284 & 145.749 & 176,33 & 160,34 \\
\hline Toplam & 3.757 & 631.849 & 722.244 & 168,18 & 192,24 \\
\hline
\end{tabular}

Genel olarak binlerce takipçisi olan siyasi kullanıcıların tweetlerinin retweet edilme ve favori eklenme oranlarının düşük olduğu görülmektedir. HDP'li kullanıcıların toplam tweet sayısı 457, tweet başına retweet sayısı 344,14 olarak gerçekleşmiştir. Toplam tweet sayısı en az olan parti HDP olmasına rağmen atılan tweet sayılarının retweet edilme sayısı, tweet başına yüksektir. MHP'li kullanıcıların toplam tweet sayısı 909 iken bu tweetlerin retweet edilme sayısı tweet başına 176,33'tür. Tweet başına retweet sayısına göre üçüncü sırada ise CHP gelmektedir. CHP kullanıcılarının toplam tweet sayısı 1.001 iken bu tweetlerin tweet başına retweet edilme sayısı 136,76 olarak gerçekleşmiştir. Kendi paylaştığı tweetlerin tweet başına retweet edilme sayısının en düşük olduğu parti ise AK Parti olmuştur. AK Partili kullanıcıların toplam özgün tweet sayısı 1.290 iken bu tweetlerin retweet edilme sayısı tweet başına 126,92'dir. Twitter kullanıcıları, siyasilerin tweetlerini favori yaparak, siyasilere ve/veya söylemlerine ilişkin ilgilerini göstermektedirler. Favori alan tweetler ve kullanıcılarının sanal ortamlardaki görünürlükleri de artmaktadır. Partilerin paylaştığı tweetlerin tweet başına favori olarak eklenme durumu hesaplandığında sırasıyla, HDP'nin tweetlerinin daha çok favori 
edildiği, diğer partilerin ise paylaştıkları tweetlere oranla daha az favori edildikleri görülmektedir.

Siyasi kullanıcıların kendi yazdıkları tweetlerinin retweetlenmesi ve favori edilmesi iletinin tekrarı açısından önemlidir. Çünkü tutum ve algıları yönlendirme sürecinde iletinin tekrarlanması ve beğeni yoluyla yayılımı mesajın alıcılar üzerindeki etkisini artıran en önemli unsurlar arasındadır. Bu açıdan genel olarak siyasilerin paylaştıkları tweetlerin düşük oranlarda retweet edilmesi ve düşük oranlarda favori alması siyasal iletişim çalışmalarında algı yönetimi açısından eksiklik olarak görülmektedir.

Tablo 5: Liderlerin Tweetlerinin Ortalama Retweet ve Favori Sayıları

\begin{tabular}{|l|c|c|c|c|c|}
\hline Tweet Sahibi & Tweet Sayısı & $\begin{array}{c}\text { Toplam Retweet } \\
\text { Sayısı }\end{array}$ & $\begin{array}{c}\text { Toplam Favori } \\
\text { Sayısı }\end{array}$ & $\begin{array}{c}\text { Ortalama } \\
\text { Retweet Sayısı }\end{array}$ & $\begin{array}{c}\text { Ortalama } \\
\text { Favori Sayısı }\end{array}$ \\
\hline Ahmet Davutoğlu & 86 & 87.520 & 145.254 & $1.017,67$ & $1.689,00$ \\
\hline Kemal Kılıçdaroğlu & 62 & 68.041 & 103.144 & $1.097,44$ & $1.663,61$ \\
\hline Selahattin Demirtaş & 18 & 125.400 & 156.958 & $6.966,67$ & $8.719,89$ \\
\hline Devlet Bahçeli & 44 & 107.601 & 99.756 & $2.445,48$ & $2.267,18$ \\
\hline Toplam & 210 & 388.562 & 505.112 & $1.850,30$ & $2.405,30$ \\
\hline
\end{tabular}

3.757 tweet arasında en fazla retweet alan tweetler ve kullanıcıları ile ilgili yapılan analizde ise retweet edilme sayısının en yüksek olduğu kullanıcılar, tüm partiler için parti genel başkanları olmuştur. Bu durum algı yönetimi çerçevesinde mesaj kaynağının popüleritesi ile ilgili olarak açıklanabilir. Buna göre, paylaştığı özgün tweetlerin tweet başına ortalama retweet sayısı en yüksek HDP Genel Başkanı Selahattin Demirtaş'ta $(6.966,67)$ görülmektedir. Demirtaş'ın en fazla retweet edilen tweeti ise, $10.761 \mathrm{kez}$ retweet edilen, 07.06.2015 tarihli, 2.399 numaralı "Halkların demokratik müşahitlerine kolay gelsin. Seçim yasağı nedeniyle gönlümdeki parti adını söyleyemiyorum, ama HDP olduğunu bilin istedim." tweeti olmuştur. Paylaştığı özgün tweetlerin tweet başına ortalama retweetlenme sayısı en yüksek olan ikinci isim ise MHP Genel Başkanı Devlet Bahçeli'dir $(2.445,48)$. Bahçeli'nin 4.977 kez retweet edilen, 10.06.2015 tarihli 2.849 numaralı "Meraklanmayın, bugün dünden daha umutlu, bugün dünden daha olumludur." tweeti en fazla retweetlenen tweetidir. AK Parti Genel Başkanı Ahmet Davutoğlu ve CHP Genel Başkanı Kemal Kılıçdaroğlu'nun tweetlerinin tweet başına retweet edilmesi birbirine yakın oranlarda görülmüștür. Ahmet Davutoğlu'nun paylaştığı özgün tweetlerin tweet başına ortalama retweet sayısı 1.017,67'dir. Davutoğlu'nun 6.045 kez retweet edilen, 06.06.2015 tarihli, 1 numaralı "Elhamdülillah..." tweeti en fazla retweet edilen tweeti olmuştur. Kemal Kılçdaroğlu'nun paylaştığı özgün tweetlerin tweet başına ortalama retweet sayısı 1.097,44' tür. Kılıçdaroğlu'nun $4.580 \mathrm{kez}$ retweet edilen 05.06.2015 tarihli, 1.299 numaralı "Unutulmasın ki milyonlarca oy bile tek bir canın karşılığı olamaz." tweeti en fazla retweet edilen tweeti olmuştur.

Tweetleri en fazla favori olarak eklenen kullanıcılar da parti genel başkanları olmuştur. Buna göre, paylaştıkları özgün tweetlerin tweet başına ortalama favori olarak eklenme durumu en yüksek HDP Genel Başkanı Selahattin Demirtaş'a aittir. Demirtaş'ın 05.06.2015 tarihli, 2.401 numaralı "BARIŞ kazanacak, bundan emin olun ve sağduyuyu elden bırakmayın" tweeti 18.337 kişi tarafından favori olarak eklenmiştir. Paylaştığı özgün tweetlerin tweet başına ortalama favori olarak eklenme durumu açısından 2. sırada ise MHP Genel Başkanı Devlet Bahçeli gelmektedir $(2.267,18)$. Bahçeli'nin 10.06.2015 tarihli, 2.849 numaralı "Meraklanmayın, bugün 
dünden daha umutlu, bugün dünden daha olumludur." tweeti 6.742 kişi tarafından favori olarak eklenmiştir. AK Parti Genel Başkanı Ahmet Davutoğlu ve CHP Genel Başkanı Kemal Kılıçdaroğlu'nun tweetlerinin tweet başına favori olarak eklenme durumu ise birbirine yakın oranlarda görülmüștür. Ahmet Davutoğlu'nun paylaștığı özgün tweetlerin tweet başına ortalama favori olarak eklenme sayısı 1.689,00'dur. Davutoğlu'nun tweetleri arasında en fazla beğeni alan tweet, 06.06.2015 tarihli, 1 numaralı "Elhamdülillah..." tweetidir ve 12.273 kişi tarafından favori olarak eklenmiştir. Kemal Kılçdaroğlu'nun paylaştığı özgün tweetlerin tweet başına ortalama favori olarak eklenme sayısı 1.663,61'dir. Kılıçdaroğlu'nun 05.06.2015 tarihli, 1.299 numaralı "Unutulmasın ki milyonlarca oy bile tek bir canın karşılığı olamaz." tweeti en fazla beğenilen tweetidir ve 5.382 kişi tarafindan favori olarak eklenmiştir.

\subsection{Partilerin Tweetlerinde Mention, Hashtag, URL,Video-Fotograf Kullanımı}

Tablo 6: Partilerin Tweetlerinde Mention, Hashtag, URL,Video-Fotograf Kullanım Sayıları

\begin{tabular}{|l|c|c|c|c|c|c|}
\hline Açıklama & Tweet Sayısı & $\begin{array}{c}\text { Hashtag } \\
\text { (\#) Kullanımı }\end{array}$ & $\begin{array}{c}\text { Mention (@) } \\
\text { Kullanımı }\end{array}$ & $\begin{array}{c}\text { URL } \\
\text { Kullanımı }\end{array}$ & $\begin{array}{c}\text { Fotoğraf } \\
\text { Kullanımı }\end{array}$ & $\begin{array}{c}\text { Video } \\
\text { Kullanımı }\end{array}$ \\
\hline AK Parti & 1.290 & 165 & 73 & 386 & 633 & 59 \\
\hline CHP & 1.101 & 85 & 39 & 161 & 378 & 25 \\
\hline HDP & 457 & 43 & 11 & 25 & 244 & 5 \\
\hline MHP & 909 & 144 & 42 & 21 & 733 & 12 \\
\hline Toplam & 3.757 & 435 & 165 & 593 & 1.988 & 101 \\
\hline
\end{tabular}

Sosyal medyanın kullanıcılarına sunduğu çift taraflı iletişim özelliği Twitter'ın mention (bahsetme) özelliği ile karşılık bulmaktadır. Kişiye özel iletişim ve ikna ilişkisinin pozitif yönü, algı yönetimi açısından Twitter'ın bu özelliğini önemli kılmaktadır. Bulgular, Twitter'ın siyasal iletişim çalışmaları açısından karşılıklı iletişim olanağı sağlayan mention (@bahsetme) özelliğinin siyasi lider ve adaylar için toplam tweetlerinin yanında çok düşük oranlarda kullanımını göstermektedir. İncelenen 3.757 tweetin sadece 165'inde $(\% 4,39)$ mention kullanımı söz konusu olmuştur. AK Parti tweetlerinin \%5,66'sı (73), MHP tweetlerinin \%4,62'si (42), CHP tweetlerinin \%3,54'ü (39) ve HDP tweetlerinin \%2,41'i (11) mention içermektedir. Söz konusu örneklem içerisinde AK Parti kullanıcıları arasında en fazla mention kullanımı Süleyman Soylu'da görülürken, MHP kullanıcıları arasında en fazla Ruhsar Demirel'de, CHP kullanıcıları arasında ise en fazla Mehmet Bekaroğlu'nda, HDP kullanıcıları arasında ise en fazla Hüda Kaya'da görülmektedir.

Elde edilen bulgular hashtag (\#etiket) kullanımının da tüm partiler düzeyinde düşük olduğunu göstermektedir. Konunun etiketlenerek daha çok kişiyle etkileşim kurulmasına olanak tanıyan hashtagler ile siyasal alanda anlatı inşa edilmekte; bu sayede konu/olay istendik hedefler doğrultusunda çerçevelenerek geleneksel mecralara göre filtresiz bir şekilde doğrudan kullanıcılara sunulmaktadır. Araştırmada partilerin ve liderlerin oluşturduğu hashtaglerin parti iletişim çalışmalarında kullanılan slogan söylemlerini içerdiğini, belirli bir konu ya da sorunu çerçeveleyerek kamuoyunu yönlendirmek amacını taşıyan kişisel söylem biçimleri olmadığı görülmektedir. Oysa hashtag kullanımı Twitter'ın siyasal yönünü harekete geçirmede güçlü bir potansiyele sahiptir. Bireylerin konu ya da olaya ilişkin gerçeklik algısını yöneten hashtagler, izler kitlenin düşünce ve davranışlarını doğrudan etkileme amacıyla siyasilere önemli firsatlar sunmaktadır. İncelenen 3.757 tweetin sadece 435 'inde $(\% 11,58)$ hashtag kullanımı söz konusu olmuştur. Hashtag kullanım 
oranı, MHP'nin kendi tweetlerinin \%15,84 (144)'ünde olmak üzere diğer partilerin kullanım oranları arasında en yüksek oranda gerçekleşmiştir. MHP kullanıcıları arasında Ruhsar Demirel en fazla hashtag kullanımına sahiptir. İkinci sırada ise AK Parti, kendi tweetleri arasında \%12,64 (163) oranında hashtag kullanmıștır. AK Parti, kullanıcıları arasında en fazla hashtag kullanımı Ahmet Davutoğlu'na aittir. HDP kendi toplam tweetlerine oranla \%9.41 (43) oranında hashtag kullanımına yer verirken, CHP ise kendi toplam tweetlerine oranla \%7.72 (85) oranında hashtag kullanımına yer vermiștir. HDP kullanıcıları arasında en fazla hashtag kullanımı Hüda Kaya'ya aittir. CHP kullanıcıları arasında ise en fazla hashtag kullanımı Sezgin Tanrıkulu'na aittir.

Twitter'ın görsel malzemelerin teşhirine uygun bir yapıya sahip olması, ileti/mesajın dikkat çekiciliği, yayılımı ve etkisi açısından önem taşımaktadır. Görsel unsurlar ile tasarımlanarak paylaşılan ileti, görselin teşhir gücü sayesinde kısa süre içerisinde daha fazla kişiye yayılmaktadır. Belirtilen süre içerisinde örneklem olarak alınan partilerin tweetlerinde görsel unsurlardan genel olarak yararlandıkları saptanmıștır. Buna göre toplam tweetlerinin 733'ünde $(\% 80,64)$ fotoğraf ve 12 'sinde $(\% 1,32)$ de video paylaşımına yer veren MHP, partiler arasında en fazla görsel unsura yer veren parti olmuştur. İkinci sırada ise tweetlerinin 633'ünde $(\% 49,07)$ fotoğraf ve 59'unda $(\% 4,57)$ video paylașıma yer veren AK Parti yer almıștır. Görsel unsura yer verme konusunda HDP ise tweetlerinin 244 'ünde $(\% 53,39)$ fotoğraf ve 5 'inde video $(\% 1,09)$ kullanmıștır. CHP tweetlerinin 377 'sinde $(\% 34,33)$ fotoğraf, 25 'inde $(\% 2,27)$ video paylaşımı yaparak alınan örneklem içerisinde bulunan dört parti arasında görsel unsuru en az kullanan parti olmuştur.

Twitter'da karakter sınırı olması bağlantı paylaşımını önemli kılmaktadır. URL/ link ile herhangi bir içeriğe bir web adresi üzerinden ulaşmak mümkün olmakta; böylece ileti/mesajın ardyöresine ilişkin daha fazla veriye ulaşma mümkün hale gelmektedir. Bireyin aldığı ileti/mesajın içerik açısından kapsamının genişlemesi, bireyin algılaması ve dolayısıyla da ikna sürecinde önemlidir. Elde edilen bulgulara göre, Tweetlerinin 386'sında (\%29,92) URL/link kullanımına yer veren AK Parti örneklem içerisine alınan dört parti arasında en fazla URL/link kullanan parti olmuştur. AK Parti'li kullanıcılar arasında URL/link kullanımında Yasin Aktay öne çıkmaktadır. Yasin Aktay tweetlerinde kendi adına oluşturduğu ve siyasal iletişim çalışmalarına ayrıntılı bir şekilde yer verdiği web adresine bağlantı vermektedir. İkinci sirada ise tweetlerinin 161'inde $(\% 14,62)$ URL/link kullanımına yer veren CHP yer alırken, üçüncü sırada ise tweetlerinin 25'inde $(\% 5,47)$ URL/link kullanan HDP yer almıștır. URL/link kullanımını en az yapan parti ise tweetlerinin 21'inde URL/link kullanan MHP olmuştur.

\subsection{Liderlerin Tweetlerinde Mention, Hashtag, URL,Video-Fotograf Kullanımı}

Tablo 7: Liderlerin Tweetlerinde Mention, Hashtag, URL,Video-Fotograf Kullanım Sayıları

\begin{tabular}{|l|c|c|c|c|c|c|}
\hline Açıkıama & $\begin{array}{c}\text { Tweet } \\
\text { Sayısı }\end{array}$ & $\begin{array}{c}\text { Hashtag } \\
\text { (\#) Kullanımı }\end{array}$ & $\begin{array}{c}\text { Mention (@) } \\
\text { Kullanımı }\end{array}$ & $\begin{array}{c}\text { URL } \\
\text { Kullanımı }\end{array}$ & $\begin{array}{c}\text { Fotoğraf } \\
\text { Kullanımı }\end{array}$ & $\begin{array}{c}\text { Video } \\
\text { Kullanımı }\end{array}$ \\
\hline Ahmet Davutoğlu & 86 & 73 & 3 & 60 & 23 & 37 \\
\hline Kemal Kılıçdaroğlu & 62 & 2 & 0 & 1 & 1 & 0 \\
\hline Selahattin Demirtaş & 18 & 0 & 0 & 1 & 4 & 1 \\
\hline Devlet Bahçeli & 44 & 0 & 0 & 0 & 0 & 0 \\
\hline Toplam & 210 & 75 & 3 & 62 & 28 & 38 \\
\hline
\end{tabular}


Liderler arasında mention kullanımı neredeyse yok denecek düzeydedir. AK Parti Genel Başkanı Ahmet Davutoğlu'nda \%3.49 (3) oranı ile görülmüştür. Diğer üç partinin genel başkanlarında mention kullanımı, belirtilen süre içerisinde saptanmamıştır.

Liderler arasında yapılan analizde tweetlerinde hashtag kullanımı en yüksek kişi AK Parti Genel Başkanı Ahmet Davutoğlu olmuştur. Davutoğlu belirtilen süre içerisindeki 86 tweetinin 73'ünde hashtag kullanmıștır. CHP lideri Kemal Kılıçdaroğlu belirtilen süre içerisinde paylaştığı 62 tweetin sadece 2'sinde hashtag kullanmıştır. MHP lideri Devlet Bahçeli ve HDP lideri Selahattin Demirtaş'ın ise tweetlerinde hashtag kullanmadıkları görülmüştür.

Görsel unsurlara tweetlerinde en fazla yer veren parti lideri Ahmet Davutoğlu olmuştur. Davutoğlu, belirtilen süre içerisinde paylaştığı 86 tweetinin 23'ünde fotoğraf kullanımına, 37'sinde video kullanımına yer vermiş; 26'sında ise görsel unsur hiç kullanmamıştır. Görsel unsur kullanımına tweetlerinde yer veren ikinci lider ise HDP lideri Selahattin Demirtaş olmuştur. Demirtaş paylaştığ 18 tweetin 4'ünde fotoğraf, 1'inde video paylaşımına yer vermiş, 13'ünde ise görsel unsur kullanmamıştır. CHP lideri Kemal Kılıçdaroğlu ise belirtilen süre içerisinde paylaştığı 62 tweetin sadece 1'inde fotoğraf kullanmış; video kullanımını ise hiç tercih etmemiştir. MHP lideri Devlet Bahçeli ise tweetlerinde görsel unsura hiç yer vermemiştir. MHP'nin tweet kullanım pratiklerinde diğer partilere göre tweetlerinde en fazla görsele yer veren parti olmasına rağmen liderler arasında MHP lideri Devlet Bahçeli'nin görsel unsurları hiç kullanmaması dikkat çekicidir.

Liderler arasında URL/link kullanıma en fazla Ahmet Davutoğlu yer vermiştir. Örneklem dâhilinde paylaştığı 86 tweetin 60'ında URL/link kullanmıştır. HDP lideri Selahattin Demirtaş, 18 tweetinin 1'inde URL/link kullanımına yer vermiştir. Kemal Kılıçdaroğlu ise toplamda paylaștığı 62 tweetin sadece 1'inde URL/link kullanmıştır. MHP lideri Devlet Bahçeli'nin ise tweetlerinde URL/link kullanmadığı görülmüştür.

\subsection{Partilerin ve Liderlerin Tweetlerinde Tema Kullanımı}

Çalışma kapsamında örnekleme dâhil edilen 4 parti ve 24 kullanıcının, 01 Mayıs 2015 - 10 Haziran 2015 tarihleri arasında hesaplarından paylaştıkları tweetlerin içerikleri temaları açısından değerlendirilmiştir. Buna göre kullanıcıların paylaştıkları 3.757 tweet arasındaki dağılımda en çok tercih edilen tema; 'Kişi/ Parti Siyasal Etkinlikler' olarak gerçekleşmiştir. En çok tercih edilen temanın, 'Kişi/ Parti Siyasal Etkinlikler' olarak gerçekleşmesi, Twitter'ın duyuru panosu formatında kullanıldığını kanıtlamaktadır. Bulgular, Twitter, karakteristik özellikleri ve imkânları ölçüsünde değil geleneksel siyasal iletişimin uygulamalarının devamı niteliğinde kullanıldığını ortaya koymuştur. Diğer temalarda tweet paylaşımının düşük olması sosyal medyanın görüş, bilgi, olgu, eleştiri sunma açısından yeterli düzeyde değerlendirilemediğini göstermektedir. Zira sosyal medyanın karakteristik yapısı ve Twitter'ın yapısal unsurları kullanıcıya geleneksel medyadan farklı olarak aracısız/ filtresiz bir şekilde diğer kullanıcılarla iletişime geçme avantajını sunmaktadır. Bu çerçevede kategoriler arası tweet kullanımının çeşitlilik göstermesi siyasal iletişim çalışmaları açısından avantajdır. Seçim kampanyalarında oluşturulan söylemin, seçmenin sosyolojik, psikolojik ve rasyonel tercihlerine hitap etmesi güçlü tutum ve algıların oluşumu için önemlidir. 
Tablo 8: Partilerin ve Liderlerin Tweetlerinde Tema Kullanım Sayıları

\begin{tabular}{|l|c|c|c|c|}
\hline Açıklama & AK Parti & CHP & HDP & MHP \\
\hline Kişi/Parti Siyasal Etkinlikler & 820 & 332 & 243 & 435 \\
\hline Vaatler & 33 & 134 & 0 & 90 \\
\hline Dilekler & 52 & 46 & 17 & 61 \\
\hline Görüş & 130 & 104 & 44 & 70 \\
\hline Polemik/Eleştiri & 155 & 283 & 91 & 112 \\
\hline Bilgi/Olgu & 58 & 84 & 21 & 25 \\
\hline Öğüt/Çağrı & 16 & 95 & 30 & 86 \\
\hline Diğer & 7 & 0 & 1 & 2 \\
\hline Kodlanamıyor & 18 & 23 & 10 & 28 \\
\hline Toplam & 1.290 & 1.101 & 457 & 909 \\
\hline
\end{tabular}

Bunagöre,AKPartitweetlerinin \%64,52'lik(820) önemlibiroranını,HDP tweetlerinin \%54,36'si (243), MHP tweetlerinin \%49,38'i (435) ve CHP tweetlerinin \%30,80'ini (332) 'Kişi/Parti Siyasal Etkinlikler' kategorisinin oluşturduğu görülmektedir. İkinci sırada en fazla tweet sayısı 'Polemik/Eleştiri' kategorisinde gerçekleşmiştir. Buna göre, 'Polemik/Eleştiri' kategorisi, CHP tweetlerinin \%26,25'sinde (283), HDP tweetlerinin \%20,36'sinda (91) MHP tweetlerinin \%12,71'inde (112) ve AK Parti'nin tweetlerinin \%12,20'sinde (155) saptanmıștır. Tweetlerinde 'Vaatler' kategorisine sahip en fazla tweet bulunduran parti \%12,43'lük (134) oranla CHP'dir. Yine MHP tweetlerinin \%10,22'si (90) bu kategoride gerçekleşmiştir. AK Parti'de bu oran ise \%2,60 (33) olarak karşımıza çıkmaktadır. HDP tweetlerinin ise 'Vaat' kategorisinde tweeti bulunmamaktadır. 'Görüş' paylaşımının yapıldığı tweetlerin oranı tüm partilerde birbirine yakın oranlarda seyrederken, 'Bilgi/Olgu' temalı tweetlerin oranı da genel olarak tüm partiler için düşük düzeydedir.

Tablo 9: Liderlerin Tweetlerinde Tema Kullanım Sayıları

\begin{tabular}{|l|c|c|c|c|}
\hline Açıklama & $\begin{array}{c}\text { Ahmet } \\
\text { Davutoğlu }\end{array}$ & Kemal Kılıçdaroğlu & $\begin{array}{c}\text { Selahattin } \\
\text { Demirtaş }\end{array}$ & Devlet Bahçeli \\
\hline Kişi/Parti Siyasal Etkinlikler & 73 & 1 & 3 & 0 \\
\hline Vaatler & 3 & 26 & 0 & 1 \\
\hline Dilekler & 8 & 12 & 1 & 1 \\
\hline Görüş & 0 & 13 & 2 & 16 \\
\hline Polemik / Eleştiri & 0 & 4 & 3 & 18 \\
\hline Bilgi / Olgu & 0 & 0 & 1 & 1 \\
\hline Öğüt / Çağrı & 2 & 6 & 7 & 5 \\
\hline Diğer & 0 & 0 & 1 & 2 \\
\hline Toplam & 86 & 62 & 18 & 44 \\
\hline
\end{tabular}

AK Parti lideri Ahmet Davutoğlu'nun tweetlerinin \%84,88'ini (73) 'Kişi/Parti Siyasal Etkinlikler' kategorisinin, \%9,30'unu (8) 'Dilekler' kategorisinin ve \%3,49'unu (3) 'Vaat' kategorisinin oluşturduğu görülmüştür. CHP lideri Kemal Kılıçdaroğlu'nun tweetlerinin ise \%41,94'ünü (26) 'Vaat', \%20,97'ünü (13) 'Görüș' ve \%19,35'ini (12) 'Dilekler' kategorisi oluşturmuştur. HDP lideri Selahattin Demirtaş, \%41,18 (7) oranıyla tweetlerinde en fazla 'Öğüt/Çağrı' temalı tweet paylaşımına yer vermiştir. 'Kişi/Parti Siyasal Etkinlikler' ve 'Polemik/ Eleştiri' temasına da eşit oranlarda tweetlerinde yer vermiştir. MHP lideri Devlet Bahçeli'nin tweetlerinde \%40,91 (18) oranıyla en fazla 'Polemik/ Eleștiri' temasını kullandığı görülmüştür. Daha sonra ise \%36,36 (16) oranıyla 'Görüş' temalı tweetlere yer verdiğinin söylemek 
mümkündür. Bahçeli'nin 'Kişi/Parti Siyasal Etkinlikler' temalı tweet paylaşımına hiç yer vermemesi ise dikkat çekicidir.

\subsection{Partilerin ve Liderlerin Tweetlerinde Kullandıkları Dil Biçimi}

Mesaj/iletinin konuşma diline yakın bir biçimde oluşturulması algı yönetimi açısından etkili iletişim ve ikna sürecinde önemlidir. İyi yönetilen bir iletişim kampanyasında, toplumun bekleyiş ve umutlarını kendi amaçları doğrultusunda biçimlendirirken günlük hayatta kullanılan dil tercih edilmesi alıcılar üzerinde olumlu bir etki oluşturmaktadır. Örneklem olarak alınan dört partinin kullanıcıları paylaştıkları tweetlerde dil biçimi bakımından büyük oranda konuşma dilini kullanmışlardır.

Tablo 10: Partilerin Tweetlerinde Kullanılan Dil Biçimi Sayıları

\begin{tabular}{|l|c|c|c|c|}
\hline Parti Adı & Yazı Dili & Konuşma Dili & Kodlanamıyor $^{\mathbf{3}}$ & Toplam $^{-1202}$ \\
\hline AK Parti & 62 & 126 & 1.290 \\
\hline CHP & 50 & 1014 & 37 & 1.101 \\
\hline HDP & 6 & 379 & 72 & 457 \\
\hline MHP & 0 & 848 & 61 & 909 \\
\hline Toplam & 118 & 3.443 & 196 & 3.757 \\
\hline
\end{tabular}

Buna göre, AK Parti'de konuşma dili ile yazılmış tweet sayısı, 1202, CHP'de 1014, MHP'de 848, HDP'de 379'dur. Yazı dili kullanımı ise örneklem için seçilen dört parti için de düşük oranda tercih edilmiştir. AK Parti 62, CHP 50, HDP 6 tweetinde yazı dilini kullanırken, MHP yazı dilini hiç kullanmamıștır.

Tablo 11: Liderlerin Tweetlerinde Kullanılan Dil Biçimi Sayıları

\begin{tabular}{|l|c|c|c|c|}
\hline Parti Lideri & Yazı Dili & Konuşma Dili & Kodlanamıyor & Toplam \\
\hline Ahmet Davutoğlu & 0 & 86 & 0 & 86 \\
\hline Kemal Kılıçdaroğlu & 7 & 55 & 0 & 62 \\
\hline Selahattin Demirtaş & 1 & 16 & 1 & 18 \\
\hline Devlet Bahçeli & 0 & 44 & 0 & 44 \\
\hline Toplam & 8 & 201 & 1 & 210 \\
\hline
\end{tabular}

Liderlerin tweetlerinde de konuşma dili kullanımı genel olarak yüksektir. Ahmet Davutoğlu ve Devlet Bahçeli' de yazı dili kullanımı hiç görülmezken, Kemal Kılçdaroğlu ve Selahattin Demirtaş'ın tweetlerinde ise yazı dili kullanımının düşük oranda da olsa kullanıldığı saptanmıştır.

\subsection{Partilerin ve Liderlerin Tweetlerinde Sözlü Kültür Kullanımı}

Siyasal aday ya da partinin bütünlüklü, canlı, sürdürülebilir bir siyaset ve iletişim bağlamını inşa etmesinde sözlü kültür unsurlarının kullanımı önemli rol oynamaktadır Siyasi aktörlerin mesaj/iletilerinin bağlamlarını inşa ederken sözlü kültür unsurlarından yararlanmaları, kurulan iletişim, akılda kalıcılık, etkililik açısından tutum ve algıların oluşmasında önemlidir.

Tablo 12: Partilerin Tweetlerinde Sözlü Kültür Kullanımı

\begin{tabular}{|l|c|c|c|c|}
\hline Parti Adı & Var & Yok & Kodlanamıyor & Toplam \\
\hline AK Parti & 393 & 877 & 20 & 1.290 \\
\hline CHP & 260 & 815 & 26 & 1.101 \\
\hline HDP & 109 & 336 & 12 & 457 \\
\hline MHP & 163 & 717 & 29 & 909 \\
\hline Toplam & 925 & 2.745 & 87 & 3.757 \\
\hline
\end{tabular}


Tweetlerde kullanılan sözlü kültür ürünleri (atasözü, deyim, özlüsöz, halk kahramanı) kullanımı genel olarak tüm partilerde düşük olarak saptanmıştır. Partiler içerisinde en fazla kullanılan sözlü kültür unsuru 'deyim'dir. AK Parti tweetlerinde deyimden sonra \%1,97 (25) oranında 'atasözü' kullanılmıștır. MHP tweetlerinde ise diğer partilerden belirgin oranda yüksek olarak \%1,59 (14) oranında 'özlü söz' kullanımı görülmüştür. CHP ve HDP'nin ise deyim kullanımı dışında atasözü ve özlü söz kullanımının AK Parti ve MHP'ye nispeten daha düşük olduğu görülmüştür.

Tablo 13: Liderlerin Tweetlerinde Sözlü Kültür Kullanımı

\begin{tabular}{|l|c|c|c|c|}
\hline Parti Lideri & Var & Yok & Kodlanamıyor & Toplam \\
\hline Ahmet Davutoğlu & 5 & 81 & 0 & 86 \\
\hline Kemal Kilıçdaroğlu & 20 & 41 & 1 & 62 \\
\hline Selahattin Demirtaş & 6 & 11 & 1 & 18 \\
\hline Devlet Bahçeli & 13 & 31 & 0 & 44 \\
\hline Toplam & 44 & 164 & 2 & 210 \\
\hline
\end{tabular}

'Deyim' kullanımı AK Parti Genel Başkanı Ahmet Davutoğlu dışındaki diğer liderler arasında yüksek oranda kullanılmıştır. CHP Genel Başkanı Kemal Kılıçdaroğlu'nun tweetlerinin 17'sinde 'deyim' kullandığı, HDP Genel Başkanı Selahattin Demirtaş'ın tweetlerinin 6'sında 'deyim' kullandığı, MHP Genel Başkanı Devlet Bahçeli'nin ise tweetlerinin 11'inde 'deyim' kullandığı görülürken, liderler arasında en yüksek tweete sahip olan AK Parti Genel Başkanı Ahmet Davutoğlu'nun ise tweetlerinin sadece 4'ünde 'deyim' kullandığı görülmüştür. 'Atasözü' kullanımı sadece MHP Genel Başkanı Devlet Bahçeli'de görülürken, 'halk kahramanı' kullanımı da yalnız AK Parti Genel Başkanı Ahmet Davutoğlu'nda görülmüştür. CHP Genel Başkanı Kemal Kılıçdaroğlu, tweetlerinde 'özlü söz' kullanımına rastlanmıştır. HDP Genel Başkanı Selahattin Demirtaş'ın ise tweetlerinde 'deyim' dışında diğer sözlü kültür unsurlarına yer vermediği görülmüştür.

\subsection{Partilerin ve Liderlerin Tweetlerinde Kullanılan Anlatım Biçimi}

Twitter'da karakter sınırlaması nedeniyle, bir tweet az sözcükle çok şey anlatmak durumundadır. Tweet ile aktarılmak istenen düşünce veya olay belirli kalıplar ve kelime grupları aracılığıyla anlam bakımından zenginleștirilerek sunulduğundan yan/dolaylı anlatımın yüksek görülmesi iletinin gücü açısından önemli görülmektedir. Tweet içeriğinde kullanılan metafor, metonimi, benzetmeler, mecaz unsurlar yan anlam içerisinde değerlendirilmiștir. Yan/dolaylı anlatım unsurlarını barındıran anlatım biçimi ve düz/ doğrudan anlatım biçimi 3.757 tweet üzerinde analiz edilmiştir.

Tablo 14: Partilerin Tweetlerinde Kullandıkları Anlatım Biçimi Sayıları

\begin{tabular}{|l|c|c|c|c|}
\hline Parti Adı & Düz/Doğrudan Anlam & Yan/Dolaylı Anlam & Kodlanamıyor & Toplam \\
\hline AK Parti & 347 & 924 & 19 & 1.290 \\
\hline CHP & 257 & 819 & 25 & 1.101 \\
\hline HDP & 127 & 318 & 12 & 457 \\
\hline MHP & 241 & 634 & 34 & 909 \\
\hline Toplam & 972 & 2.695 & 90 & 3.757 \\
\hline
\end{tabular}

Partilerin tweetlerinde hâkim olan anlatı dili yan/dolaylı anlatı yapısıdır. $\mathrm{Bu}$ oran örneklem için alınan dört partinin tweetlerinde de birbirine yakın oranlarda saptanmıştır. 
Tablo 15: Liderlerin Tweetlerinde Kullandıkları Anlatım Biçimi Sayıları

\begin{tabular}{|l|c|c|c|c|}
\hline Parti Lideri & Düz/Doğrudan Anlam & Yan/Dolaylı Anlam & Kodlanamıyor & Toplam \\
\hline Ahmet Davutoğlu & 5 & 81 & 0 & 86 \\
\hline Kemal Kılıçdaroğlu & 4 & 58 & 0 & 62 \\
\hline Selahattin Demirtaş & 5 & 12 & 1 & 18 \\
\hline Devlet Bahçeli & 1 & 42 & 1 & 44 \\
\hline Toplam & 15 & 193 & 2 & 210 \\
\hline
\end{tabular}

Liderlerin tweetlerinde de yan/dolaylı anlatı yapısının yüksek olduğu görülmektedir. Yalnız HDP lideri Selahattin Demirtaş'ın toplam tweetlerine oranla diğer liderlere göre düz/doğrudan anlatı yapısına daha fazla yer verdiği saptanmıştır.

\section{Sonuç ve Değerlendirme}

Sosyal medyanın karakteristik yapısı ve Twitter'ın yapısal unsurları hedef kitle üzerinde istenilen doğrultuda algı oluşturmak için önemli potansiyel gücü taşımaktadır. Özellikle politik içerikli bilgi paylaşımında son yıllarda öne çıkan Twitter, kullanıcı ile direkt iletişime geçme (mention), iletiyi aynen paylaşma (retweet), harici bağlantı (URL) kullanma ve etiketler (hashtag) yoluyla kamuoyu olușturabilme özellikleri ile algı yönetiminde önemli bir kitle iletişim aracı konumundadır. Twitter'ın bireysel kullanımların ön plana çıktığı bir araç olması, bu mecradaki söylemi etkileyici iletişim ve ikna çalışmaları açısından da önemli hale getirmektedir.

Nitel ve nicel içerik çözümlemesi yöntemiyle elde edilen araştırmanın bulguları değerlendirildiğinde, Twitter'ın Türk siyasiler tarafından yeterince işlevsel olarak kullanılmadığı, geleneksel siyaset yapma pratiklerini bu ortamda devam ettirdikleri, Twitter'ı yoğunlukla duyuru-reklam panosu formunda kullandıkları görülmüştür. Siyasilerin bu mecrayı seçmen kitle ile iletişim kurmak yerine diğer kullanıcılar yokmuş gibi davranarak, geleneksel medya araçlarının bir uzantısı olarak kullanma eğiliminde oldukları saptanmıştır. Parti ve lider bazında tweetlerin içerikleri temaları açısından değerlendirildiğinde kullanım farklılıkları olmakla birlikte 3.757 tweet arasındaki dağılımda en çok tercih edilen temanın, 'Kişi/Parti Siyasal Etkinlikler' olarak gerçekleştiği görülmektedir. 'Polemik/Eleştiri' temalı tweetlerin sayısı da diğer kategorilere göre nispeten yüksek olarak saptanmıș, ancak ideolojik temele dayanan görüş paylaşımının yapıldığı tweet sayısı, herhangi bir konu/olay hakkında seçmeni bilgilendirme amacı taşıyan tweet sayısı ise oldukça düşük olarak saptanmıştır. Oysa kategoriler arası tweet kullanımının çeşitlilik göstermesi siyasal iletişim çalışmaları açısından avantajdır. Seçim kampanyalarında oluşturulan söylemin, seçmenin sosyolojik, psikolojik ve rasyonel tercihlerine hitap etmesi güçlü tutum ve algıların oluşumu için önemlidir.

Sosyal ağ sitelerinin etkileșimli potansiyeli, geleneksel siyasal iletişimin tek yönlü doğası karşısında gün geçtikçe daha da ilgi çekmektedir. Twitter, siyasal iletişim ve algı yönetimi ilişkisinde, siyasi aktörlerin hedef kitleleriyle çok yönlü iletişim kurmaları için avantajlara sahip bir sosyal medya uygulamasıdır. Twitter kullanıcıları, siyasilerin tweetlerine olan ilgilerini retweet ederek ve favori (beğeni) yaparak göstermektedirler. Ancak araştırmada elde edilen bulgular, genel olarak binlerce takipçisi olan siyasi kullanıcıların tweetlerinin retweet edilme ve favori (beğeni) oranlarının düşük olduğunu göstermektedir. Oysa retweet edilme, Twitter'da mesaj yayılımı için önemli bir mekanizmadır. Bilgi yaymak için hızlı ve interaktif bir yoldur. Araştırmalar, sosyal medya sitelerinde paylaşımın, kullanıcının 
iletiyi yaymak suretiyle diğer kullanıcıları ikna etme motivasyonu sağladığını ortaya koymaktadır. Bu anlamda tweetin retweet edilmesi ve bu şekilde kitlelere yayılımı, kişiler üzerinde gerçeklik algısını kuvvetlendiren güdülenme sağlayacağından algı yönetiminde önemlidir.

Çalışmada Twitter'ın siyasal iletişim çalışmaları açısından karşılıklı iletişim olanağı sağlayan mention (@bahsetme) özelliğinin siyasi lider ve adaylar için çok düşük oranlarda kullanımı saptanmıştır. Siyasilerin seçmenlerle çift taraflı iletişim biçimi kurma yönünde bir pratik geliştirmedikleri, hedef kitleler üzerinde etkili bir ikna stratejisi olan birebir iletişimin sosyal medya mecralarında siyasiler tarafından yeterince bilinçli kullanılmadığı sonucuna ulaşılmıştır. Oysa geleneksel siyasal iletişim çalışmaları yıllarca gücünü seçmenlerle yapılan yüz yüze görüşmelerden, kurulan birebir iletişimden almıştır. Teknolojik gelişmeler ve medyanın çeşitlenmesi yolu ile siyasal iletişim değişim yaşamış ancak birebir iletişimin seçmen üzerindeki psikolojik etkisi azalmamıştır. Bu yüzden Twitter'ın kullanıcılara, diğer kullanıcılarla etkileşime girme noktasında sunduğu yüzyüze iletişimin faydalarını online ortamında birleştiren bu özellik önemli bir avantaj olarak siyasiler tarafından değerlendirilmelidir.

Araştırmada Twitter kullanım pratikleri açısından elde edilen bulgulardan biri de partilerin hashtag kullanımlarıdır. Buna göre hashtag (\#etiket) kullanımının da tüm partiler düzeyinde düşük olduğunu söylemek mümkündür. Hashtaglerin kullanımı ile geleneksel medyadaki gündem başlıklarına paralel ya da siyasi parti ve adayların önemsedikleri alternatif bir konu gündeme taşınabilmektedir. En çok konuşulan hashtag ise TT (Trending Topic-Hakkında En çok Konuşulan Konu) listesine girmektedir. Böylelikle kullanıcıların ortak bir konu etrafında konuşabilmesini sağlayan hashtag kullanımı ile bir bakıma sosyal medya kendi kamusal mekânını yaratarak gündem oluşturmakta ya da gündemi etkilemektedir. Filtresiz/aracısız iletilerle kullanıcılarla bir araya gelme avantajını yaşayan siyasiler için Twitter'ın konu/ileti çerçeveleyen hashtag uygulaması algı yöneten aktöre oldukça elverişli bir ortam sunmaktadır.

Görsel kültürün hayatımızı çepeçevre kuşattığı bu çağda, paylaşılan iletilerin görsel unsurlarla tasarımının birey algısı üzerindeki etkisi oldukça önemlidir. Bu durum, iletişim kampanyaları açısından, Twitter'ın fotoğraf ve video gibi görsel unsurların paylaşımına yer veren bir yapıya sahip olmasını önemli kılmaktadır. $\mathrm{Bu}$ açıdan bakıldığında yapılan araştırmada elde edilen bulgular partilerin sosyal medya aracılığıyla yürüttükleri siyasal iletişim çalışmalarında görsel unsurlara yer verdiklerini ve bu bakımdan algı yönetimi açısından başarılı bir strateji yürüttüklerini göstermektedir.

Karakter sınırlaması olan Twitter'da link/URL kullanımı, iletinin kapsamının genişlemesinde etkili bir unsur olarak işlev görmektedir. Araştırmada elde ettiğimiz bulgular genel olarak parti ve lider bazında link/URL kullanımının düşük düzeyde yapıldığını göstermektedir. Özellikle iletinin ardyöresine ait bilgi/belgelere erişimin sağlanması aracılığıyla kamuoyunun bilgilendirilmesi siyasiler için önemli bir avantajdır. Ayrıca siyasilerin, iletilerini parti politikalarına ait unsurlarla desteklemek, anti propagandaya karşı görmezden gelme durumunu kişiye aşılamak amacıyla da çevrimiçi çoklu kaynak imkânının eş zamanlı olarak sunumu açısından link/URL kullanımını tercih etmeleri algı yönetimi açısından önemli görülmelidir. 
Çalışmamızda elde edilen önemli bir sonuç, Twitter'ın ileti içeriklerinde, sözlü iletişimin ve sözlü kültürün izlerini taşıdığının saptanmasıdır. Türkçe karşılığı "cıvıltı" olan 'tweet' de sözlü iletişimi çağrıştırmaktadır. Bu mecra, sözlü iletişimin etkileşim, doğallık ve biraradalık özelliklerini taşımaktadır. Geleneksel kitle iletişim araçlarına göre birey bu mecralarda daha rahat iletişim kurmaktadır. Günlük yaşam ve iletişime açık yapısı ile Twitter kullanıcıları sözlü kültürde olduğu gibi iletişim kurarken daha katılımcı, daha coşkulu ve daha taşkındırlar; hatta kullanıcıların sözlü üretimlerinde genel olarak bir yarışma dinamiği içinde oldukları söylenebilir. Olumlu ya da olumsuz duygularını dile getirirken yazılı iletişimde olduğu gibi ölçülü değildirler. Yaptığımız çalışmada elde ettiğimiz bulgular, Twitter'da üretilen içeriklerde konuşma dilinin yüksek oranda kullanıldığını, konuşma dilinin kullanımına bağlı olarak sözlü kültür ürünlerinin (deyim, atasözü, özlüsöz) yoğunlukla kullanıldığını ortaya çıkarmıștır. Ayrıca tüm kullanıcılar düzeyinde tweet içeriklerinde yan anlam kullanımı (metafor, metonimi) yüksektir. Tweet ile aktarılmak istenen düşünce veya olay belirli kalıplar ve kelime grupları aracılığıyla anlam bakımından zenginleștirilerek sunulduğundan yan/dolaylı anlatımın yüksek görülmesi iletinin algıları etkileme gücü açısından önemli görülmektedir. Twitter'ın, siyasal aday ya da parti üyelerine sözlü kültür unsurlarını kullanabildiği bir mecra sunması, bütünlüklü, canlı, sürdürülebilir bir siyaset ve iletişim bağlamını inşa etmesi açısından önemli görülmelidir.

Bu çalışma 7 Haziran 2015 genel seçimlerinin Twitter'da yürütülen siyasal iletişim çalışmaları yönelik, partilerin kullanım pratikleri, içerik ve sunum biçimlerine yönelik profili, algı yönetiminin temel unsurları çerçevesinde ortaya koyma çabasının bir ürünüdür. Çalışma ile genel olarak sosyal medyanın ve sosyal medyanın siyasi yönü olarak son yıllarda kullanımı artan Twitter'ın, yapısal özellikleri doğrultusunda algı yönetiminde taşıdığı potansiyel gücün önemi ortaya konulmaktadır. Çalışma bu yönüyle siyasilere yapacakları siyasal iletişim çalışmalarında Twitter'ı nasıl daha etkili kullanacakları konusunda farkındalık oluşturmakta ve bu konuda öneriler sunmaktadır. Çalışmanın bir önerisi olarak, Twitter'ın algı yönetimindeki rolünün seçmen tarafındaki etki boyutunu anlamaya yönelik bir saha çalışmasının yapılması konunun irdelenmesi adına önemli bir araştırma olarak işlev görebilir.

\section{Notlar}

${ }^{1}$ Kod yönergesinde Bayraktutan vd. (2013) çalışması ile Doğu vd. (2013) çalışmasından faydalanılmıştır.

${ }^{2}$ Tablodaki partiler alfabetik sıraya göre düzenlenmiştir.

${ }^{3}$ Sadece bağlantı adresleri, fotoğraf, video ya da buna benzer iletilerin paylaşıldığı tweetler, herhangi bir dil biçimi içermediğinden kodlanamamıştır.

\section{Kaynaklar}

Akyazı, E. ve A. Akyazı. (2013). Suskunluk Sarmalı Perspektifinden Sosyal Medya, A. Algül, N.Üçer (Ed.) Yeni Medya'da Demokrasi (s. 225-240). Konya: Literatürk Yayınları.

Baldini, M. (2000). İletişim Tarihi, İstanbul: Avcıol.

Başıbüyük O. (2014). Algı Yönetimi ve Bilgi Savaşlarında Sosyal Medyanın Rolü, B. Karabulut (Ed.) Algı Yönetimi (s. 39-65). İstanbul: Alfa Yayınları 
Bayraktutan, G., Binark, M., Aydemir, A. T., Çomu, T., Doğu, B., ve İslamoğlu, G. (2013). "Sosyal Medya Ortamlarının Siyasal İletişim Uygulamaları Açısından İncelenmesi: Türkiye'de 2011 Genel Seçimlerinde Facebook ve Twitter'in Siyasi Partiler ve Liderler Tarafından Kullanılması." Ankara: Tübitak.

Callamari P. ve D. Reveron. Chine's Use of Perception Management, International Journal of Intelligence and Counter Intelligence, 16, 2003, 1-15.

Coleman, S. (2005). Direct Representation: Towards a Conversational Democracy. IPRR Exchange, http//www.ippr.org/ecomm/files/Stephen_Coleman_ Pamphlet.pdf

Coşkun, H. (2013). Tutum Değișimi. H. Coşkun (Ed.), Sosyal Psikoloji (s.135-160). İstanbul: Lisans Yayıncılık.

Çebi, S. M. (2003). Kitle İletişimi Araçlarının Gerçekliğin Yansıtılması ya da Kurulması Süreçlerindeki Rolü. İletişim Kuram ve Araştırma Dergisi, 17, 111-142.

Çomu, T. ve İ. Halaiqa. (2014). Web İçeriklerinin Metin Temelli Çözümlemesi, M. Binark. (Ed.) Yeni Medya Çalışmalarında Araştırma Yöntem ve Teknikleri (s. 88-116). İstanbul: Ayrıntı Yayınları.

Doğan, E. (2013), Siyasal Seçimlerde Kullanılan Görsellerde Anlamın Yaratılması: 2011 Genel Seçimlerinde AK Parti ve CHP Kampanyaları. İstanbul Üniversitesi Sosyal Bilimler Enstitüsü Radyo-Televizyon-Sinema Ana Bilim Dalı. Yayınlanmamış Doktora Tezi. İstanbul.

Domenach, M. J. Politika ve Propaganda, (T. Yücel, Çev.), Varlık Yayınları, İstanbul, 1995.

Entman, R.M. (1993). Framing: Toward clarification of a fractured paradigm. Journal of Communication, 43(4), 51-58.

Eren, V., Aydın, A. (2014). Sosyal Medyanın Kamuoyu Oluşturmadaki Rolü ve Muhtemel Riskler. KMÜ Sosyal ve Ekonomik Araştırmalar Dergisi ,16, 197-205.

Erol, S. M.,ve Ozan, E. (2014). Türk Dış Politikasında Algı Yönetimi. B. Karabulut (Ed.), Algı Yönetimi (s.185-209). İstanbul: Alfa Yayınları.

Ersaydı, S. Ç. (2011). Psikolojik Operasyon,Algı Yönetimi ve Propaganda. http:// www.21yyte.org/tr/arastirma/milli-guvenlik-ve-dis-politika-arastirmalarimerkezi (Erişim Tarihi: Nisan 2018).

Garfield, A. The Offence of Strategic Ifluence: Making The Case for Perception Management Operations, Journal of Information Warfare, 1(3), 2002, 30-39.

Gökçe, O. (2012). Yeni Medya, Kamuoyu, Demokrasi. E. Sözen (Ed.) Hepimiz Globaliz Hepimiz Yereliz (s. 36-54). İstanbul: Alfa Yayıncılık.

Gurevitch, M., Coleman, S., \& Blumler, J. G. (2009). Political communication-Old and New Media Relationships. The Annals of the American Academy of Political and Social Science, 625(1), 164-181.

High, A.C. and D.H. Solomon (2011). Locating Computer-Mediated Social Support Within Online Communication Environments. Computer-mediated communication in personal relationships. 119-136. 
Hong, S., Nadler, D. (2012). Which Candidates Do The Public Discuss Online in an Election Campaign? The Use of Social Media by 2012 Presidential Candidates and its Impact on Candidate Salience. Government Information Quarterly, 29, 455-461.

İnceoğlu, M. (2011). Tutum Algı İletişim. (6. bs.). Ankara: Siyasal Kitabevi.

Jensen, K. B. (2011). New Media, Old Methods-Internet Methodologies and the Online/Offline Divide. Mia Consalvo ve Charles Ess (Ed.) The Handbook of Internet Studies (s.43-58). Malden: Wiley-Blackwell.

Kağıtçıbaşı, Ç. ve Z. Cemalcılar. (2014). Dünden Bugüne İnsan ve İnsanlar. (16. bs). İstanbul: Evrim Yayınları.

Kapko, M. (2016). Twitter's Impact on 2016 Presidential Election is Unmistakable. CIO Retrieved http://www.cio.com/article/3137513/social-networking/ twittersimpact- on-2016-presidential-election-is-unmistakable.html April 2018.

Keskin, S. ve M. F. Sönmez. (2015). “Liderler Ve Takipçileri: Siyasi Parti Liderlerinin Twitter Performansları ve Takip İlişkisi. "Selçuk Üniversitesi İletişim Fakültesi Akademik Dergisi, 9(1), 339-362.

Le Bon, G. (2014). Kitleler Psikolojisi. (H. Can, Çev.). Ankara: Tutku Yayınevi. (1895).

Lee, J., Song, H. (2017). Why people post news on social networking sites: A focus on technology adoption, media bias, and partisanship strength. Electronic News,11(2), 59-79.

Lilleker, D. G. (2013). Siyasal İletişim:Temel Kavramlar. (B. Ekşi, Çev.). İstanbul: Kaknüs Yayınları.

Meriç, Ö. (2015). 140 Karakter ile Siyaset Konuşmak: Twitter ve Siyasetçi-Yurttaş Etkileşimi. S.E. Karakulaoğlu ve Ö. Uğurlu (Ed.), İletişim Çalışmalarında Digital Çalışmalar Twitter (s.33-59). Heretik Yayınları.

Milburn, A. M. (1998). Sosyal Psikolojik Açıdan Kamuoyu ve Siyaset. Ankara: İmge Kitabevi.

Morris, C. G. (2002). Psikolojiyi Anlamak. (Çev. Belgin Ayvaşık ve Melike Sayıl) Ankara: Türk Psikologlar Derneği Yayınları.

Mutlu, E. (2000). İletişim Sözlüğü. Ankara: Sofos Yayınları.

Ong, W. J. (2014). Sözlü ve Yazılı Kültür: Sözün Teknolojileşmesi. (5. bs.). (S.Postacıoğlu Banon, Çev.) İstanbul: Metis Yayınları (1982).

Özer, M. A. (2012). Bir Modern Yönetim Tekniği Olarak Algılama Yönetimi ve İç Güvenlik Hizmetleri. Karadeniz Araştırmaları, 147-180.

Perception, Process and terminology. (t.y.). Erişim Tarihi: 07.07.2018.

http://enclopedia.thefreedictionary.com/Perception management.

Richards, B. (1994). Disciplines of Delight: The Psychoanalysis of Popular Culture. London: Free Association Books.

Saydam, A. (2014). Algılama Yönetimi. (6. bs.). İstanbul: Remzi Kitabevi. 
Taylor, P., L. A Peplau ve D. O. Sears. (2012). Sosyal Psikoloji. (A. Dönmez, Çev.) Ankara: İmge Kitabevi.

Tosuner, A. (2015). İnternet Aktivizminde Twitter'ın Stratejik Konumu. S. Ö. Karakulakoğlu ve Ö. Uğurlu (Ed.), İletişim Çalışmalarında Digital Yaklaşımlar Twitter (s.117-145. Ankara: Heretik Yayınları.

Turan, K., (2014). Toplum Mühendisliği, Siyaset Mühendisliği ve Algı Yönetimi. B. Karabulut (Ed.). Algı Yönetimi (s.97-117). İstanbul: Alfa Yayınları.

Türk, M.S., (2014). Algı Yönetimi ve İletişim: Algının Ötesinde Bir Gerçeklik Var mı?, B. Karabulut (Ed.), Algı Yönetimi (s.13-39). İstanbul: Alfa Yayınları.

Uğurlu, Ö. (2015). Gerçek Olanın İkame Alanı Olarak Twitter: Online Dünyada Yönetilen Algılar. S. Ö. Karakulakoğlu ve Ö. Uğurlu (Ed.), İletişim Çalışmalarında Digital Yaklaşımlar Twitter (s.295-307). Ankara: Heretik Yayınları.

Yeşilyurt, Y. (2015). Twitter'da Sözlü, Yazılı ve Görsel Kültürün İzleri. S. Ö. Karakulakoğlu ve Ö. Uğurlu (Ed.), İletişim Çalışmalarında Digital Yaklaşımlar Twitter (s.73-93. Ankara: Heretik Yayınları.

Yıldız, M. (2013). Sosyal Medya Toplumsal Algı ve Devlet. İdarecinin Sesi Dergisi, 156, 56-58. 
